and 40 on

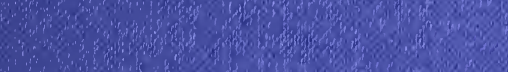

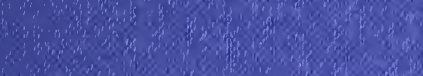
and

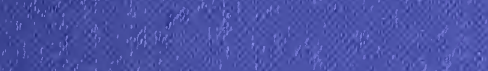

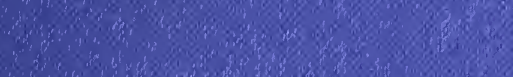

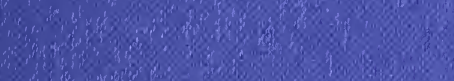
in 3

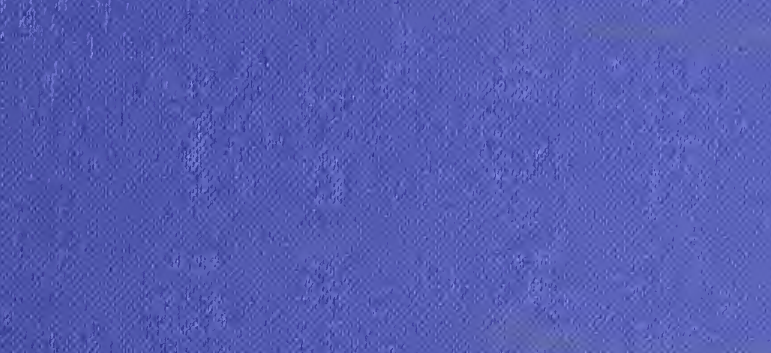

10.0. a (2.2. -

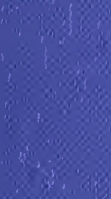
2.

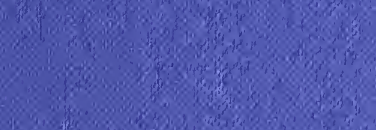

-1.

-

1.5.

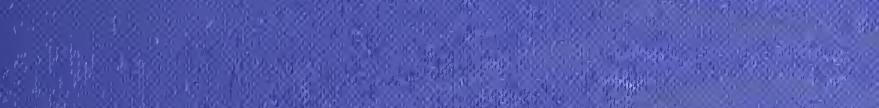

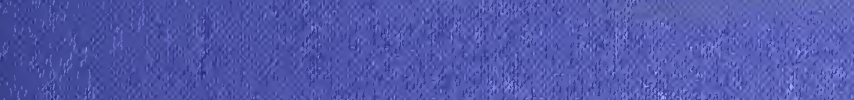

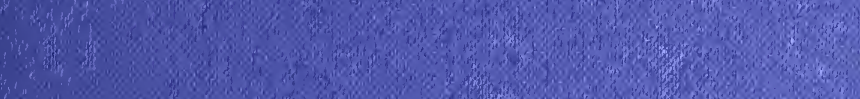
(1) 3.5.

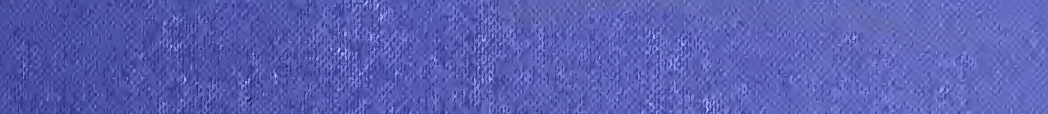
(1) (2)

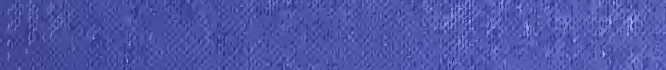
6.

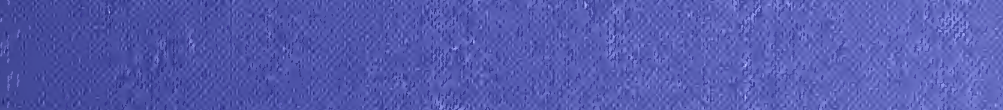



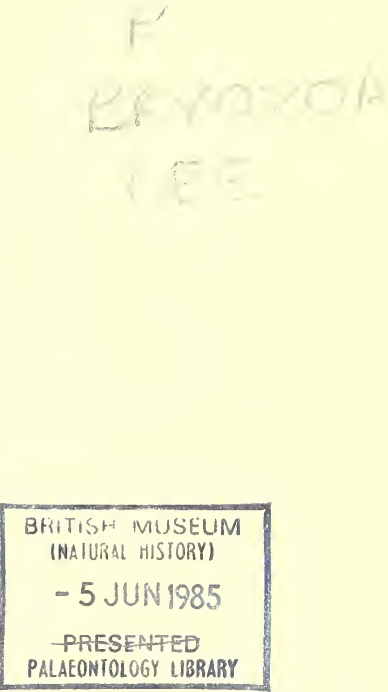

$$
\begin{aligned}
& \text { TBRYOZOOH } \\
& \text { So ct? }
\end{aligned}
$$




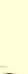





\title{
MEMOIRS OF THE GEOLOGICAL SURVEY OF GREAT BRITAIN.
}

PALAONTOLOGY.

\author{
VOL. I. PART 3. \\ Pages 135-195; Plates, XIV.-XVI.
}

\section{The British Carboniferous Trepostomata.}

\author{
BY \\ G. W. LEE, D.Sc.
}

PUBLISHED BY ORDER OF THE LORDS COMMISSIONERS OF HIS MAJESTY'S TREASURY.

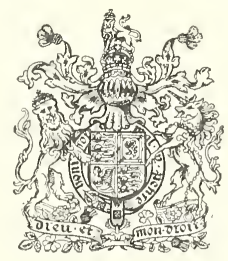

L O N D O N :

PRINTED FOR HIS MAJESTY'S STATIONERY OFFICE, BY DARLING \& SON, LTD., 34-40, BACON STREET, E.

And to be purchased from

E. STANFORD, 12, 13, and 14, LONG ACRE, LONDON ;

W. \& A. K. JoHNSTON, Ltid, 2, St. ANdrew SQUare, Edinburgh ;

HODGES, FIGGIS \& Co., Grafton Street, Dublin ;

From any Agent for the sale of Ordnance Survey Maps ; or through any Bookseller, from T. FISHER UNWIN, 1, ADELPHI TERRAcE, LoNDON, W.C., who is the Sole Wholesale Agent to the Trade outside the County of London.

[ISsUed MAY 24TH.]

1912.

Price Three Shillings. 


\section{CONTENTS.}

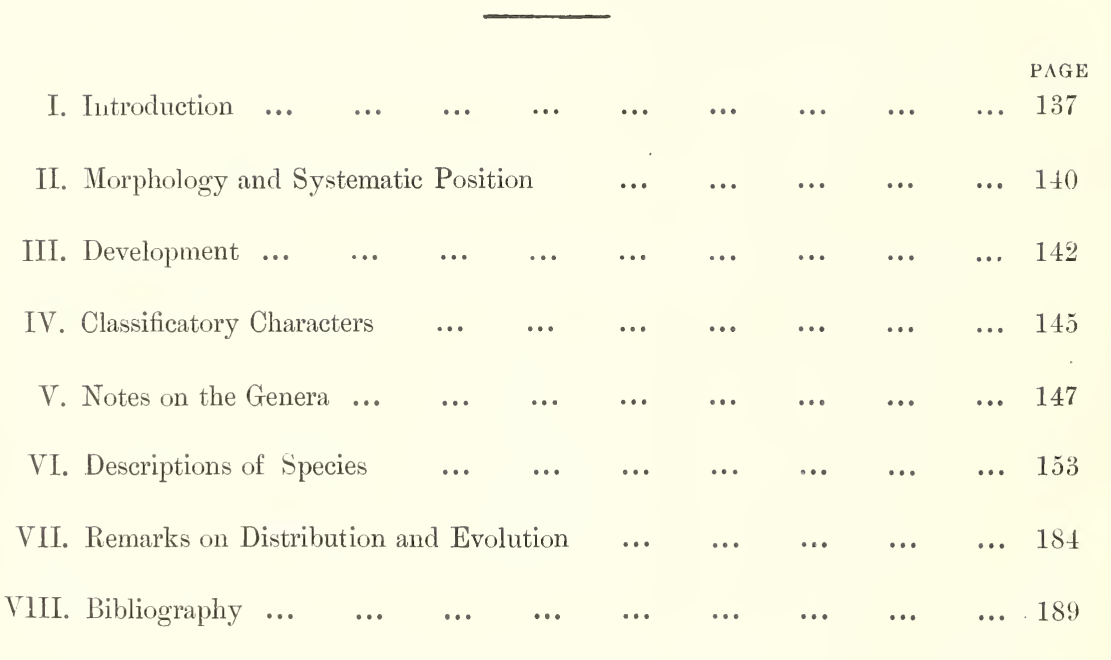




\section{THE BRITISH CARBONIFEROUS TREPOSTOMATA.}

\section{I.-Introduction.}

A cursory review of the more salient points in the history of research among the Trepostomata will show that there is urgent need that the British representatives of this widespread sub-order should be classified, and as far as possible described, so as to permit of their being made use of by investigators.

Abundant as the Trepostomata are now known to be in the Palæozoic deposits of various regions, the investigation of their nature depends on the use of the microscope; and as the older authors necessarily based their determinations on external features only, it is not surprising that but few species were recognised until the middle of the second half of the last century. Previous to that time the ramose mode of growth was thought to be the principal characteristic of the group, which was generally referred to the Tabulate Corals and restricted to a very limited number of species credited with a long vertical range and wide horizontal distribution. No systematic work was attempted, and new names-in the West of Europe at least--became speedily buried in synonymic lists.

$\mathrm{M} \cdot \mathrm{Coy}$, who was in so many ways in advance of his contemporaries, suspected the importance of the group, without, however, proposing a classification. ${ }^{1}$

In 1866 a bold step was taken by C. Rominger in advocating the removal to the Bryozoa of several forms allied to "Chatetes," and similar conclusions were expressed by Lindström in $1873 .^{3}$

In the year 1877 appeared Dybowski's memoir on the Chætetids of the East-Baltic Silurian, and two years later Nicholson's monograph of the Tabulate Corals. These two works-especially the latter-mark a new era in this branch of research, showing the absolute need of thin sections and careful microscopical examination. The importance of the impetus they gave to subsequent study can hardly be overestimated. ${ }^{4}$ Regarding the systematic position of the Monticuliporids, no definite conclusions were reached by Dybowski, but Nicholson maintained that their affinities are with the Tabulate Corals, which riew he continued to hold in his later works.

In the classification adopted by von Zittel in the original edition of his "Handbuch der Palaeontologie," published from 1876 to 18s0, the Monticuliporids form with Chaetetes

${ }^{1} 21$, p. $193 . \quad \quad 235 a . \quad{ }^{3} 17 a . \quad 45 a ; 25$.

(22239-17.) Wt. 26725-59. 301. 5/12. D. \& S. 
proper the family Chaetetidae, placed in the Bryozoa Cyclostomata ; it is therefore of interest to note that in the latest edition of his "Grundziige" Nicholson's classification is reverted to. ${ }^{1}$

It may be stated here that the greater part of Nicholson's observations bore on materials of American source, mostly Siìrian and Devonian. He recognised but two species of British Carboniferous Monticuliporids, viz., "Monticulipora" tunida (Phill.) and Stenopora howsei Nich.

An able contemporary of Nicholson was J. Young of Glasgow. He took a keen interest in the Scottish Carboniferous Bryozoa and in a short note published in 1883 proposed the new genus Tabulipora for the reception of the common Scottish Monticuliporid. ${ }^{2}$

Of Vine's contributions, there is little touching the British Carboniferous Monticuliporids that can be of use to the student, his only addition to the fauna, Heterotrypa delicatula Vine, being too insufficiently characterised to be recognisable. ${ }^{3}$

Research on the Carboniferous Trepostomata of Britain ceased with the labours of Nicholson, Young, and Vine, and our knowledge of this group of British fossils is as it was left by these three investigators. Of the five species proposed at different times, Stenopora housei Nich. is the only one that can be readily identified from the author's description. The true nature of M'Coy's Verticillopora dubia could not be ascertained without examination of the holotype, fortunately preserved. As for Cellepora urei Flem., Calamopora tumida Phill. and Heterotrypa delicatula Vine., these names must be discarded, the holotypes being lost and the descriptions totally inadequate.

The largest share of the work done during the last thirty years on Palæozoic Bryozoa belongs to American authors, and specially to Mr. E. O. Ulrich. In $1882^{4}$ he began the publication of a monograph describing the Palrozoic Bryozoa of America. The Monticuliporidae are considered as Bryozoa and constitute his sub-order Trepostomata of the Bryozoa Gymnolaemata. The classification proposed in this important work and in subsequent large monographs by the same author on the Palæozoic Bryozoa of Illinois and Minnesota has gained general recognition in America, and is laid along lines in harmony with the requirements of modern palæontology.

The modern literature on the Trepostomata of other countries is not very voluminous, and mainly of a descriptive nature. One of the most widely known accounts is that by Waagen and Wentzel on the Monticuliporids of the Productus Limestone of the Salt-Range. ${ }^{5}$ In this work, published in 1887, they give accurate descriptions
${ }^{1} 51 a$.
${ }^{2} 50$, p. 154.
${ }^{3} 48$, p. 386.
${ }^{4} 41$.
${ }^{5} 49$. 
not only of Indian materials, but also of the common "Stenopora" columnaris (Schloth.), of the Permian deposits of Western Europe. The current interpretation of Lonsdale's genus Stenopora rests on the earlier definitions of Nicholson and Etheridge ${ }^{1}$, insufficient attention having been paid to an exhaustive memoir by $\mathrm{Mr}$. Etheridge, published in $1891^{2}$, in which a new diagnosis is given, based on the examination of numerous Australian topotypes.

The Upper Carboniferous rocks of Russia are rich in Trepostomata. Several descriptions of new forms, together with a revision of the old diagnoses of Lonsdale, Eichwald and Trautschold, are to be found in the monographs of Stuckenberg ${ }^{3}$ and Romanowski. ${ }^{4}$

Although the Trepostomata can now be said to be well known as regards their morphology, there is still a branch of their study that awaits detailed research, namely, their ontogenetic development. Such work was attempted by Lindström, ${ }^{5}$ and many valuable remarks have been made by Nicholson and by Ulrich, but an exhaustive study similar to that of Mr. Cumings on the development of the Fenestellids has yet to appear. ${ }^{6}$

The principal object of the present contribution is to provide the working palæontologist with the means of giving an intelligible record of the occurrence of forms which, on account of their general distribution, are likely to prove of value in zoning the Carboniferous rocks of this country.

Since the identification of the various species of Trepostomata rests on the interpretation of outstanding and structurally important features, it has been found possible to classify them in a satisfactory way; and in this respect the methods used are somewhat comparable with those applied to the Corals, Once the principles of classification have been mastered, most forms can readily be identified and comparisons between the better characterized species can be effected by means of fairly exact terms.

Throughout the following pages, the register-numbers of individual specimens are given in square brackets. The specimens are in the Survey collections, except when otherwise stated.
${ }^{1} 26,27,28,29$.
27.
${ }^{3} 38,39$.
${ }^{4} 35$.
${ }^{5} 18$.
${ }^{6} 3,4$. 


\section{II.-Morphology and Systematic Position.}

$\begin{array}{lll}\text { Class } & \text { B r yozo a } & \text { Ehrenberg. } \\ \text { Order } & \text { Grmnomamata } & \text { Allman. } \\ \text { Sub-Order } & \text { Trepostomata } & \text { Ulrich. }\end{array}$

Definition.-The above classification was proposed by Ulrich ${ }^{1}$ in 1882 , and is now almost universally recognised, there being at present but few upholders of the former view that the branching, massive or encrusting colonies typified by Monticulipora were Tabulate Corals ${ }^{2}$ allied to the Favositidae or the Chaetetinae.

The distinguishing character of the Trepostomata is that the zoarium or colony is composed of fasciculated tubes-the zorecia - which in their proximal portion are thinwalled and prismatic, while near the end of their course they change in character and direction, becoming thick-walled and bending outwards. The zoarium-when ramoseis thus divisible into two regions: an axial region comprising the proximal ends of the zoœcia, and a peripheral region comprising their distal ends. The axial and peripheral regions are also known respectively as "immature" and "mature"; these last-named terms are probably not quite appropriate, but, until better ones are suggested, are of use when dealing with laminar or other irregular zoaria whose shapes would be incompatible with the use of the term "axial."

In the majority of species the zoœcia are crossed by transverse partitions known as diaphragms or tabula, whose nature and arrangements have considerable classificatory value.

In a number of genera small differentiated cells-known as mesopores-occur between the zoœcia proper. They differ from the zoøecia proper not only in size but also in being more or less angular, with a difference in the nature of the tabulation, which is generally closer.

The acanthopores are blunt spines projecting above the general surface. 'In tangential sections-i.e., shallow sections crit parallel to the surface-they appear as circular spots darker than the general tissue, and often showing a small central lumen.

Since the mesopores and acanthopores were presumably occupied by specially modified polypides, it follows that a colony in which they occur is composed of more than one kind of element, and is therefore heteromorphic.

The monticules are small elevated areas composed of zoccia larger than the average. The maculce are small depressed areas made up of cells smaller than the average.

$$
{ }^{1} 41, \text { p. } 149 . \quad 251 a, \text { p. } 114 .
$$


Carboniferous species with monticules have not yet been detected in Britain, but maculæ are of frequent occurrence. These are extremely sporadic, and do not seem to obey any definite laws as regards their distribution within any given zoarium. These assemblages of modified zoøcia, presumably for protective purposes, fall within the category of topomorphs ${ }^{1}$, a term recently suggested by Mr. W. D. Lang.

Note on the interpretation of certain sections. - The sections must be made as thin as possible, as apart from the mere difficulty of observation, thick slides are apt to be misleading, and this is specially the case with longitudinal sections prepared with the view of observing the nature and distribution of the tabulæ.

Tabulæ may be complete or perforated, that is, provided with a perforation which may be central, sub-central, or lateral. In longitudinal sections complete tabulæ will appear as uninterrupted lines stretching from wall to wall. If in a well-made slide the plane of section passes through the lumen of a perforated tabula, the tabula will appear as two opposed lines separated by a central or sub-central interval, according to the position of the lumen. But if the thickness of the slide exceeds the diameter of the lumen the chances are that the appearance exhibited by a perforated tabula will be that of a complete tabula. This can be tested by the simple process of frequently examining an unfinished slide of a specimen known to belong to a species with perforated tabulæ: it will be seen that while the section is still comparatively thick, the tabulæ appear as complete lines, gradually evincing signs of the perforation as the thickness diminishes. There is yet another case of misleading appearance which does not depend on the thickness of the slide, but on the position of the plane of section, which may often happen to pass outside the radius of the lumen, so that the tabula appears as complete. But in any given zoarium the number of zoœcia, and consequently of tabulæ, is generally so great that the perforation-if any-is bound to be shown at various points.

In a number of British species the perforation is lateral, and occupies a distal position relatively to the direction of growth of the zoarium, so that a section cut normally to the direction of growth is more liable to be misleading than one containing the longer axis of the zoarium, as shown by diagrams, plate xiv., figs. 1 and 2. Very thick longitudinal sections cutting the zoccia-walls tangentially sometimes show a series of parallel lines roughly simulating tabulae; but they are really zones of specially dense sclerenchyma passing through the wall-substance. 


\section{III.--DeVelopMent.}

Mr. E. R. Cumings has proposed ${ }^{1}$ certain terms expressing successive stages of growth of the colony of the Bryozoa: the terms nepiastic, neanastic, ephebastic, and gerontastic being adjectives corresponding to an infant, adolescent, mature, or senile colony. Although these terms were originally applied to frondescent forms such as Fenestella, they can equally well be applied to other growth-shapes as met with among the Trepostomata.

Examples of a trepostomatous Bryozoon in the phylastic stage, ${ }^{2}$ or earliest stage capable of fossilisation, presumably exist in the British Carboniferous rocks, but at the outset one would be confronted by an almost insuperable difficulty in attempting to refer them to their proper systematic position. The youngest colonies that can safely be identified are in the form of patches encrusting various solid objects such as crinoid stems or shells. This stage marks the termination of encrusting growth in forms that produce erect zoaria, and can therefore be referred to the metanepiastic stage of Cumings. At this stage the zoøcia are attached to a basal membrane, often described as epitheca, for which Prof. Gregory has recently proposed the more appropriate designation of epizoarium. ${ }^{3}$ The zoœcia, in the thinnest crusts observed, differ in no way from the zoœcia of the adult portion of the colony, except in point of size, being at first prostrate and thin-walled, then suddenly bending at a considerable angle and assuming the thickening characteristic of the Trepostomata. Acanthopores are likewise developed at this early stage, and tabulæ are present in very thin crusts (plate xv., figs. 15, 16), though, owing probably to some accidental cause, not one is shown in the aspect depicted in plate xv., fig. 14.

Bryozoa, like other organisms, sometimes skip certain stages of development, ${ }^{4}$ but in the case of the ramose Trepostomata the metanepiastic stage could not be skipped, since an erect branching colony must necessarily have an expanded base of attachment. On the other hand, certain colonies may preserve for a long time the growth-shape characteristic of the metanepiastic stage, though actually an old colony possessing a thick "mature" region. A good example is the colony encrusting an Aclisina which accompanies the holotype of V'Coy's Verticillopora dubia : the former is made up of zoœcia actually larger than is the case in the latter.

To the neanastic stage, which begins with the assumption of the habit of budding, ${ }^{5}$ are referred colonies consisting of a crust throwing off small branches. An important point is that at this stage - at least, in the British forms examined-the colony has the faculty of adopting indifferently two courses. In the one case the epizoarium raises itself
${ }^{1} 3$, p. 50 .
${ }^{2}$ Op. cit., pp. 54-56.
-313 , p. xx.
${ }^{4}$ 3. p. 59
${ }^{5}$ Op. cit., p. 59 . 
from its base of attachment, thus forming an invagination or tube lining the zoœcia. This process may stop at any point or persist throughout the ephebic stage, that is, in full sized branches. The result is a hollow branch which may attain the full size of the species, or a branch which is at first hollow and afterwards solid, that is, made up of fasciculated zoœcia shaped so as to constitute the axial and peripheral regions alluded to. This is, however, by no means an invariable succession. Several examples of Tabulipora howsei (Nich.) preserved in the Nicholson Collection show a tubular, epizoarial stage following, in the same branch, the solid stage. How the organism had the faculty of suddenly secreting an epizoarium is not easily explained. In the second case the epizoarium does not raise itself, and the branches are solid, the branching mode being effected solely by the zoœcia taking up the fasciculated arrangement. In both cases the branches are almost always of uniform diameter throughout, tapering only near the end, and incipient secondary branches can be as thick as, or even thicker than, the motherbranch.

It has already been mentioned that the zoœcia of a nepiastic colony do not differ from those of an ephebic colony except in point of size, i.e., the relative dimensions of the axial and peripheral regions are the same. Furthermore, large suites of ephebic colonies belonging to the same species show conclusively that in each species the dimensions of the axial and peripheral regions not only are invariably the same in branches of the same diameter, but also that in the smallest as well as in the largest these two regions have invariably the same relative proportions. In other words, the ratio between axial region and diameter in solid cylindrical branches is in each species constant, whatever the size of the branch. Thus, in Stenopora redesdalensis the ratio of axial region to diameter is $0.7: 1$ (rounding the second decimal), as in plate xiv., fig. 5 ; in Tabulipora scotica it is $0 \cdot 6: 1$, as in plate xiv., fig. 4 ; and so on. To put it still more graphically, were one to superpose a series of sections of different sizes, the peripheral region of the smaller would partly coincide with the axial region of the larger.

Were these organisms not differentiated into two regions characterized by the unequal thickness of the walls, this constant relative proportion could perhaps be explained by assuming - as probably done by Sardeson — - that the growth-activity was distributed throughout the whole length of the zoœcial tubes, and regulated in such a way as to respect the relative proportions. The finer histological features shown by thin sections are however against this assumption; the outer thickened region exhibits a clearly laminated structure, while the proximal end of the walls is apparently structureless and so thin

$$
{ }^{1} 35 b \text {. }
$$


that it is not easy to conceive of it having taken an active part in the growth of the zoøcium. And one would moreover think that the presence of tabulæ would be an obstacle to the distribution of the soft living parts. That is, the laminated structure of the outer region points to successive periodic depositions of sclerenchyma, and therefore to distal growth.

But if distal growth be admitted, then it becomes difficult to reconcile it with the fact that the respective dimensions of the axial and peripheral regions are constant whatever the size of the branch, unless we imagine the intervention of a factor which would produce proximally the gradual elimination of the greater part of the wall substance as growth proceeds distally ; that is, that there is resorbtion. On the basis of this suggestion we may conceive of the growth of a ramose form taking place as follows :-

The initial branch begins as a protuberance the diameter of which is within the limits of size possible for the species. The accumulation of sediment necessitates an upward direction of growth. In order to achieve this end and at the same time accommodate themselves to the space at their disposal, the zoœcia situated in the centre of the extremity are practically straight throughout their course, while the distal end of those that are farther from the centre has to be bent at a considerable angle in order to reach the surface. That is, the end of the branch tapers owing to the ends of the zoœcia diverging from an imaginary axis. This divergence creates an increase of space which, as pointed out by Ulrich, leads to the distal thickening of the wall and the formation of interzoœcial cells. ${ }^{1}$

As growth proceeds, new tubes are interpolated in the central portion of the extremity, while the tubes which occupied that position in the stage just considered, have to leave their previously straight course and bend in order to reach the surface, at the same time resorbing the thickening of their walls in that central position (see diagram, plate xiv., fig. 3). From the above assumption it would seem that the branch possesses its full diameter from the beginning - an hypothesis substantiated by the fact that when a branch divides the secondary branches can be as thick as the mother branch-and consequently that size is not an indication of age.

Besides furnishing a possible explanation of the growth of the colony, the resorption hypothesis may throw some light on the raison d'etre of structures otherwise not easily accounted for. By assuming that any portion of the axial region was at some time situated distally, we can account for the fact that acanthopores are often present in the axial region, although their function must have been connected with the surface of the zoarium, as pointed out by Cumings. ${ }^{2}$ 
On the same grounds one could explain the absence or rarity of the tabule in the axial region, or their complete absence in some species. It would be strange that organisms on the whole similar should have differed in such an essential respect as the complete absence of tabule throughout their existence. It might then be suggested that the non-tabulated species were tabulated during a certain period of their existence, but had the faculty of resorbing their tabulæ as they grew.

In connection with the suggestion put forward here, it is interesting to note a remark of Ulrich, that" "In the Trepostomata and many Cryptostomata, the tubular zoœcium. really represents a series of superimposed cells." Although this statement is not further elaborated it is nevertheless interesting as it seems to imply a conception which is not antagonistic to the one sketched here.

Assuming that growth took place as suggested in the preceding remarks, we are led to the not improbable conception of a phylembryonic colony consisting of straight zoœcia, thick-walled throughout.

\section{IV.-Classificatory Characters.}

Although this memoir is primarily descriptive, the remarks made in the preceding pages were necessary in order to explain the course adopted in the selection of the classificatory characters on which it is here proposed to base the British Carboniferous species.

Structure of the walls.-Ulrich and Bassler recognize two great divisions in Trepostomata Amalgamata and Trepostomata Integrata. The first includes those families in which the boundaries of adjacent zoœcia are obscured by the more or less complete amalgamation of their walls, and the second the families in which the boundaries of adjacent zoœcia are sharply defined by a black divisional line ${ }^{2}$. In the British fauna, so far as examined, a black line is occasionally exhibited in forms which are otherwise referable to the division Amalgamata. Its adoption as a classificatory character in the case of the materials considered here would lead to an inconsistent grouping of the species, and is therefore deferred pending further investigation.

The purely morphological characters of the walls are readily observable and have been widely used in specific and generic diagnoses. That is, the thickness of the walls relatively to the size of the enclosed zoœcial cavities is a tolerably constant character in a given species, while the shape of the wall as seen in long sections is often distinctive, 
certain shapes being typical of certain genera. For instance, a beaded appearance due to periodical cessations of thickening are typically developed in species of Stenopora and Tabulipora and was long thought to be restricted to the former, but this feature is now known to occur in certain Lower Palrozoic forms, e.g., Stigmatella spinosa U. \& B. and Dekayia subfrondosa Cumings.

Tabulct-The tabulæ offer in the British forms very reliable characters. Their distribution hardly varies within each species, while their nature, that is, whether they are perforate or complete, seems to be absolutely constant. No British species has yet been met with in which the tabula are not all of the one type. Strictly speaking there would be an exception in the case of Tabulipora, in which a concave plate sometimes covers the perforation of the tabulæ. It is possible that this curious body was always present, though not actually attached to the tabulæ, and preserved only in exceptional cases. Some of the old diagnoses imply the irregular occurrence of both complete and perforate tabule in the same zoœcium, but this is doubtless to be attributed to faulty observation, excepting of course those forms in which the two types of tabulæ are distributed according to a definite arrangement, as in Hemiphragma.

Acanthopores. - Considerable taxonomic value is attributed to the acanthopores. Some caution must be exercised when examining tangential sections, since the appearance presented by the acanthopores necessarily varies in some degree according to whether the plane of section cuts them near their point of origin or near their distal end. Once due allowance is made for this, it will be seen that they offer fairly reliable characters, varying within each zoarium not so much in their size as in their distribution.

Surface features.-The surface features of the zoœcia, as exhibited by the British Carboniferous species, are generally too variable and equivocal to be of service. For instance the thickness of the partition between the zoœcial apertures varies, in the same branch, within wide limits, and the same applies to the spine-like projections of the acanthopores. Species based on these surface-characters alone are unrecognizable, as for example Heterotrypa delicatula Vine, which was based on features common to widely different species.

Mode of Growth.-As already stated, the ratio of axial region to diameter, in cylindrical forms, is an excellent criterion. In the majority of the species the peripheral portion of the zoœcia is at right angles to the surface. There are, however, some species in which that portion is bent at a wider angle, and since no forms have yet been observed showing the co-existence of the two modes, specific importance is here given to the angle at which the zoœcia bend in order to reach the surface. 
There are wide differences of opinion regarding the taxonomic value of the growthshape in Bryozoa generally, and the difficulties encountered by workers on Mesozoic and Tertiary Bryozoa are also met with in the study of the Palæozoic Trepostomata. Owing perhaps partly to the fact that suites of complete zoaria are very difficult to obtain, thus often precluding the possibility of observing the merging of one growth-shape into another, the majority of workers seem to have agreed to give specific-even genericvalue to the mode of growth. As, moreover, it has in several cases been shown to express systematic difference, it is safer to recognise it whenever the materials do not show transitional growth-shapes that would justify the merging of the forms.

In the British fauna a very common type of purely individual variation is exhibited by many of the ramose species, which may be indifferently solid or hollow, the two modes sometimes co-existing in the same branch. It is interesting to note that this tendency is more pronounced in some species than in others. Stenopora redesdalensis and Tabulipora howsei exhibit it in a remarkable degree, while it does not seem to obtain in other species, for instance $T$. scotica.

\section{V.-Notes on the Genera.}

The species examined are referable to six genera. Future investigation may show some of these to be too comprehensive, while others may ultimately prove not to be true genera. But a certain degree of uncertainty in the generic divisions is at present unavoidable, the materials studied being in many cases too meagre to allow a satisfactory phylogenetic arrangement.

Genus Stenopora Lonsdale.

Lonsdale's original diagnosis is as follows. "A ramose, spherical or amorphous tubular polypidom; tubes polygonal or cylindrical, radiated from a centre or an imaginary axis, contracted at irregular distances but in planes parallel to the surface of the specimens; tubular mouths closed at final period of growth ; ridges bounding the mouths granulated or tuberculated; additional tubes interpolated." ' Although this gives a faithful description of the external characters of most species of Stenopora, it is insufficient for the needs of modern palæontology, since it was drawn up before the introduction of the use of thin sections. Lonsdale's description was, however, good 
enough for its time, and Stenopora found a general acceptance; but owing to the nonrecognition of the taxonomic value of internal characters, it was made to cover a heterogeneous assemblage of forms which happened to agree in their external features.

Nicholson was the first to undertake a revision ${ }^{1}$ of the genus based on modern methods of research, and the examination of topotypes led to a diagnosis in which stress is laid on the beaded appearance of the walls as seen in long sections. The tabulæ are described as complete. In "The Genus Monticulipora" and in his memoirs in collaboration with Mr. R. Etheridge, Jun.,2 complementary descriptions are given, the important point of which is that the tabulæ are then regarded as perforate. The modern interpretation of the genus rests essentially on the labours of these two authors, and is thus summarised by Ulrich :-

"Zoaria ramose, sub-lobate, massive, laminar or parasitic. Surface even or montiferous. Zoœecia-walls periodically thickened in the mature region. Large acanthopores at many of the angles between the zoœcia. Mesopores never very numerous, irregularly distributed. Diaphragms sometimes very scarce, but in most American species abundant in the peripheral region, and with a large central perforation. Subcarboniferous to Coal Measures." 3

The above interpretation being now firmly rooted in modern literature, it is unfortunate that it has to be modified owing to the fact that an important memoir of Mr. Etheridge, containing an unexpected emendation, somehow failed to be noticed in recent works, although it was published in $1891^{4}$. Mr. Etheridge, after a renewed examination of Australian topotypes is led to the conclusion that in the genus Stenopora the tabulæ are really complete ${ }^{5}$, as stated by Nicholson in his first description. According to Mr. Etheridge, a peculiar accumulation of calcite, of post-mortem origin, produces a deceptive appearance, previously intepreted by Nicholson and himself as being that of perforated tabulæ. Mr. Etheridge's view is strengthened by the fact that the Indian Stenoporae described by Waagen and $\mathrm{Wentzel}^{6}$, which are closely allied to the Australian species, are delineated as having complete tabule. Using Mr. Etheridge's description as a basis, the emended diagnosis of the genus Stenopora is as follows :-

Zoaria ramose, sub-lobate, massive, frondescent, laminar or parasitic. Surface even or with maculæ and monticules. Zoøcia-walls usually periodically thickened in the mature region, but sometimes of uniform thickness. Acanthopores present. Mesopores absent, but a cell smaller than the average is occasionally present at the junction-
125, p. 168.
${ }^{2} 28,29$.
344 , p. 277.
47.
5 Op. cit., p. 47.
${ }^{6} 49$. 
angles of adjacent zoœcia. Tabulæ complete, scarce to numerous. Carboniferous to Permian (?). Genotype : Stenopora tasmaniensis Lonsdale.

As regards the systematic position of Stenopora, it would be inconsistent to leave it in the family Batostomeliidae Ulrich, since all the members of that family have perforated tabulæ. On the other hand it agrees in most respects with the definition of the family Amplexoporidae Ulrich; therefore it is here suggested that it be tentatively regarded as an aberrant genus of that family, characterized by a strong tendency to the development of beaded walls.

Stenopora as defined includes Australian and Indian species, and the British fauna contains forms which agree in most respects, the only difference being that the black divisional line is here either inconspicuous or absent. But from the figures of Etheridge and of Waagen and Wentzel, it appears that the black line is sporadic even in the typical species, so that its absence in the British forms ought not to warrant their removal to a new genus until more is known of the conditions which affect the degree of visibility of this particular feature. At the same time it is admitted that the attribution of British Lower Carboniferous forms to a genus erected for the reception of Australian Upper Carboniferous or Permo-Carboniferous species, may some day be shown to be wrong, since the characters common to the species of these two provinces might be due to convergence. It will however be conceded that pending conclusive proofs to the contrary, the most convenient course is to regard the Australian and British forms as congeneric.

\section{Genus Tabulipora Young.}

It will be seen from the above description that a number of species described as Stenopora cannot be united with this genus, since they have perforated tabulæ. That such species should be removed to another genus has been recognized by Mr. Etheridge, ${ }^{1}$ who proposes to revive Young's genus Tabulipora. The erection of this genus for the reception of the common Scotch Stenoporoid, "Ure's Millepore," was certainly justified, but owing to the misconception regarding the true characters of Lonsdale's genus, Tabulipora has generally been regarded as a synonym of Stenopora.

Since Young did not give ${ }^{2}$ a condensed diagnosis of his genus, bat a description of the species for which he erected it, a diagnosis based on Young's materials and on congeneric species is given as follows:-

Zoaria generally forming solid or hollow branches, or parasitic, sometimes laminar.

$$
{ }^{1} 7, \text { p. } 47 . \quad{ }^{2} 50, \text { p. } 154 .
$$


Surface even or with maculæ. Zoœcia-walls periodically thickened in certain species, uniform in others. Acanthopores present. No mesopores, but a small cell is sometimes present between adjacent zoœcia. Tabulæ present in all the typical species, always perforated. Genotype: Tabulipora scotica sp. nov. [= Tabulipora urei Young (pars)]. Carboniferous.

As explained later, the specific name "urei" is not retained here for two reasons. The first is that Young did not really propose it as a new specific name, but assumed his materials to be conspecific with Fleming's C'ellepora urei and as Fleming's type, i.e. Ure's "Millepore," is lost, the retention of the name would imply specific identity, and this cannot be proved. The other reason is that Young's materials include several species, and as he gave no figures it is impossible to select one as the type with the specific name proposed by Young. But, fortunately, all these species are undoubtedly congeneric, so that the identity of the genus is fully established.

The genus Tabulipora possessing the characters formerly attributed to "Stenopora" of authors (non Lonsdale), it naturally falls in the family Batostomellidae, where "Stenopora" was placed by Ulrich.

The British species described here as Tabulipora are divisible into two groups or sections, characterized the one by the central or sub-central position of the perforation, the other by its lateral position. Were future investigations to prove that these two types of structure are the result of different lines of development, a new generic name would have to be proposed for the second section, but such a step is at present not necessary.

As regards the structure of the walls, the Scottish materials conclusively prove that in this genus the periodical thickening has at most specific value only, insensible gradation being observable on the same slide between strongly beaded walls and walls of uniform thickness.

\section{Genus Batostomella Ulrich.}

This was erected in 1882, ${ }^{1}$ and diagnoses have been given from time to time. The following is transcribed from Nickles and Bassler's "Synopsis" :-

"Zoarium ramose, branches slender ; zoœcia with few diaphragms; apertures of zoœcia small, circular or oval; interspaces rounded or canaliculate, spinulose, the acanthopores small and usually very numerous; mesopores small, with sub-circular openings:" 
So far only one species of Batostomella is known from the Carboniferous rocks of the British Isles.

\section{Genus Leioclema Ulrich.}

Leioclema was erected in 1882 for the reception of Callopora punctata Hall ${ }^{1}$. As it has been made to include a large number of species since its publication, it is deemed advisable to cite here a recent diagnosis rather than the original one. The diagnosis given by Nickles and Bassler" is as follows :-

"Zoarium ramose, lamellar, subglobose or incrusting ; surface frequently exhibiting distinct monticules or maculæ; zoœcia with subcircular or irregularly petaloid apertures, separated by abundant angular mesopores, which in some species are open at the surface, in others closed; diaphragms few in the zoœcia, abundant, sometimes crowded in the mesopores; acanthopores numerous and strong in the typical species, small and inconspicuous in the others."

No definite statement appear's to have been made by American authors as regards the nature of the tabula, but since all the published figures-including those illustrating the internal structure of the genotype, given in Ulrich and Bassler's "Revision "3_show complete tabulæ, the genus Leioclema is here understood as possessing complete tabulæ.

In North America Leioclema ranges from the Silurian to the Carboniferous, and is one of the most important and prolific of the American Trepostomata. It is therefore surprising that only one British representative of the genus should so far have come under notice from the Carboniferous rocks, although the conditions prevailing in the British area during Carboniferous times were generally favourable to the development of the Trepestomata.

\section{Genus Drscritelda Girty.}

Dyscritella is a name introduced by Dr. Girty, ${ }^{4}$ who uses it in a sub-generic sense to include two American Lower Carboniferous species having many characters in common with Batostomella and Leioclema, but differing from either genus in the absence of tabulæ in both mesopores' and zoøecia.

Beside two species which fall in every respect under the definition given by Dr. Girty, the British fauna contains two forms which differ in having a few tabule in the zoccia. As there seems to be a gradual transition from the typical untabulated species to the more
141, p. 154.
231, p. 33.
${ }^{3} 45$, pl. xi., figs. 7-9.
${ }^{4} 11 a$, p. 193. 
tabulated form, it is proposed here to modify the original diagnosis so as to include species having more or less tabulated zoccia. This step is more convenient than to propose for the tabulated group a new generic designation which - apart from the fact that it might possibly be proved unwarranted from a phylogenetic point of view-would be of difficult application when dealing with forms in which the tabula can be so scarce as to escape observation.

Geinitzella Waagen and Wentzel includes forms having the essential characters assigned here to Dyscritella, but as Waagen and Wentzel $^{1}$ did not indicate which of their several "varieties" was to be taken as genotype, the genolectotype must be the first in order of description, i.e., Geinitzella ramosa, var. incrustans, ${ }^{2}$ which is a species devoid of mesopores. Had these authors reversed the order of description, the "variety" multiyemmata - which has numerous untabulated mesopores ${ }^{3}$-could have been selected as genolectotype, so that Geinitzella might have been made to include the species for which the name Dyscritella is used here.

There is a close similarity of structure between the untabulated species of Dyscritella and the genus Anaphragma Ulrich and Bassler ${ }^{4}$ trom the Ordovician rocks of America. But as no species of Anaphragma appears to have been recorded from higher horizons the resemblance is probably merely homœomorphic.

\section{Genus Koninckopora gen. nov.}

This genus is proposed for the reception of Calamopora inflata de Kioninck. Its systematic position is uncertain, and it may not he a trepostomatous Bryozoon, but it is included here for the sake of convenience.

Since the type-species alone is known, a strict generic diagnosis covering all the possible variations from the type, can naturally not be given, but the main characters of the genotype may be summarized as follows:-

Colony composed of a thick epizoariun which may be tubular or folded upon itself, bearing very short erect zoœcia which are not differentiated into axial and peripheral regions. Mesopores, acanthopores and tabulæ absent.

This short abstract, insufficient in itself, is enough to show the position of the genus relatively to the other genera described in this contribution. A full description is given on p. 182.

${ }^{\text {I }} 49$, p. $880 . \quad 249$, p. 883, pl. 106, figs. $5,6$.

3 Op. cit., pl. 112, fig. 2 ; pl. 113, figs. 2 , t. 445, p. 49. 


\section{VI.-Descriptions of Species.}

Genus Stenopora Lonsdale. ${ }^{1}$

Stenopora ReDesdalensis sp. hor.

$$
\text { Plates XIV, fig. } 5 \text { A--5 D ; XV, figs. 1, } 2 .
$$

1881. Monticulipora (Heterotrypa) tumida Nicholson. On the Structure and Affinities of the Genus Monticulipora and its Sub-Genera, p. 120, plate iii., fig. 1.

Description.-(a.) External characters. The zoarium is ramose, the branches being cylindrical, varying in diameter from 2 to $6 \mathrm{~mm}$. The branches assume either the solid or the bollow mode of growth, the two forms being equally common. The branching usually takes place in one plane, more rarely in more than one plane.

Maculæ of smal!, thick-walled cells, are common. No monticules have been observed. The zoœcia-apertures are circular or sub-polygonal, according to the thickness of their partitions. There are some thirty apertures along a distance of $1 \mathrm{~cm}$. The acanthopores are of two sizes : fairly large ones are limited to the junction-angles, while more numerous but smaller ones occur in a single row hetween the apertures whenever these are separated by thick partitions.

(b.) Internal structure. Longitudinal sections show that the zoccia are, in the centre, parallel to the long axis of the branch and bend gradually ontwards until the final portion of their course is at right angles to the surface. The zoœcia-walls are extremely thin from their proximal end to that portion of their course where they assume the final change of direction. From that point to their distal end they are greatly thickened, the change in thickness being sudden, without transition. The thickening of the walls is generally not nniform, but is effected more or less periodically, so that most walls, as seen in section, have a roughly moniliform appearance. The alternations of the thickening process are not strongly marked and occur at relatively long intervals, consequently the beading is much less pronounced than in the more typical species of the genus.

Tabula are sparsely represented in the axial region and are generaily localised in the sub-peripheral portion of the tubes, none having been observed in the outer portion of the peripheral region. The interval separating them is slightly more than their own diameter. They are straight or very seldom concave.

${ }^{1}$ An emended description of the genus is given on p. 148. 
Longitudmal and transverse sections, and fractured specimens, show that the ratio of axial region to the diameter of the branch is invariably equal to $0.7: 1$ (rounding off the second decimal), whatever the size of the branch.

As seen in tangential sections the acanthopores are not very conspicuous. Both sets are somewhat irregularly represented, even in the restricted area of a single section. The large ones, occupying the junction angles of the zoœcia, are deep-rooted and are consequently observable in sections cut a considerable distance below the surface. The smaller ones, numbering at most ten to each zoœcium, are confined to the outer layers of the peripheral region, and may easily be unrepresented in a given section, if the latter is cut too deep.

The main diagnostic features of the species are the ratio of the axial region to the diameter, and the localisation of the tabulæ in the sub-peripheral region.

Distribution.-This species, as delineated here, is abundantly represented in the Redesdale Ironstone shale, at Redesdale, Northumberland, where both the solid and hollow types of branching co-exist. It is also very common at Bellingham and Lewisburn, from which localities only solid branches have been observed, and at Clattering Ford, Cumberland, where hollow branches only have so far been obtained. It occurs also at two other localities in the Bewcastle district. In Scotland it occurs at Lawston Linn, Liddisdale, and at Arbigland. These localities lie approximately on the same horizon near the middle of the Visean. The first of these occurrences and that at Lawston Linn have been assigned to the D1 zone by Mr. Stanley Smith and Dr. A. Vaughan respectively. ${ }^{1}$

Comparable species.-Forms possibly allied to Stenopora redesdalensis, but too insufficiently represented to warrant a separate description, occur in the South-West Province. In the Geological Survey Collection there are two specimens [Pr. 3482, Pr. 3483] from Lydstep Quarry, 3 miles W.S.W. of Tenby, Pembrokeshire (upper sub-zone of Seminula), which have a general resemblance to Stenopora redesdalensis, but differ from it in being thicker-walled and in having a few tabulæ in the peripheral region. Specimen Pg. 1824, from a cliff about 235 yards S.E. of Stackpole Quay, Pembrokeshire, in beds doubtfully referred to the lower sub-zone of Seminula, has a similar tabulation, but its walls are thicker and uniform, and its acanthopores appear to be of one size only. Stenopora dulia (M'Coy) from the lower Limestone of Cookstown, Ireland, is distinguished by the close tabulation of its peripheral region. A specimen of 
limestone (M. 273) from the Birkwood burn, Lesmahago, Lanarkshire, contains numerous examples of a Stenopora agreeing in its main features with Stenopora redesdalensis, but differing from it in having much smaller acanthopores, the zoarium being also smaller. The bed it comes from is either in the upper portion of the Calciferous Sandstone or at the base of the (Scottish) Lower Limestones, that is, at the top of the Visean.

Observations. - The name redesdalensis is given here to the species which Nicholson described as Monticulipora (Heterotrypa) tumida Phill., and the description is based principally on Nicholson's own materials, represented by some 500 specimens preserved in the Geological Department of Aberdeen University. A new name was called for, since, the type specimen of Phillips" "Calamopora tumida" being lost, the attribution of any form to that species is not permissible, owing to our entire ignorance of its taxonomic position.

It will be seen that there are some discrepancies between the above description and that of Nicholson, who states that the walls do not exhibit the moniliform structure, and that tabulæ are present in the peripheral region. The first statement depends possibly on a question of individual appreciation, Nicholson having probably estimated that the rather weak beading of the walls in this species was not to be compared with the distinct beading obtaining in other species, in which it is a more striking feature. As regards the second statement, it ought to have been qualified: when tabulæ are present in the peripheral region, they are restricted to its inner portion. Moreover, the examination of two slides in the Nicholson collection-which agree very well with the longitudinal section, fig. 1e, loc. cit.-suggests that the features delineated as tabule in the outer portion of the peripheral region of the specimen represented in the above quoted figure, are probably not tabulæ but zones of dense sclerenchyma.

It is hardly necessary to add that the Redesdale species is, according to the modern views, neither a Monticulipora nor a Heterotrypa. As regards its attribution to the genus Stenoprora, it must be understood that it is made under the reservation expressed in the concluding portion of the notes on that genus (p. 149).

The specimen from which the section figured, plate xv, figs. 1, 2, was prepared, belonged to materials kindly lent by Dr. A. Vaughan and had been collected by Mr. S. Smith from the Redesdale Ironstone Shale. 
Stenopora hadDingtonensis sp. nov.

Plate XV, figs. 3, 4 .

Description.-(a.) External characters. The zoarium is composed of cylindrical branches, solid in the examples that have so far come under notice, and averaging $2 \mathrm{~mm}$. in diameter.

The apertures are oval, and number some thirty-five along a distance of $1 \mathrm{~cm}$. The junction-angles are usually occupicd by the aperture of a cell much smaller than the average. The interspaces are fairly constant in thickness and bear a row of large close-set acanthopores, seemingly of one size only. No maculæ or monticules have been observed.

(b.) Internal structure. Longitudinal sections show that the zoceia are in their proximal portion parallel to the direction of growth of the colony, and after that bend gradually to the peripheral region, where, after a sharper change of direction, they are nearly at right angles to the surface. The increase in the thickness of the walls in the peripheral region is sudden and considerable. The thickening is practically uniform, there being only the faintest suggestion of moniliform structure.

Tabule are present in both the axial and peripheral regions, but are more specially abundant in the portion immediately preceding the peripheral region.

The specimens examined are interesting in that they offer the rather unusual instance of acanthopores visible in longitudinal section. In the slide figured pl. xv, fig. $t$, the plane of section is not absolutely median and a thin film of sclerenchyma consequently obscures the zoccial cavities. It is in this film that the acanthopores are shown as dark lines alternating with lighter ones.

The ratio of axial region to diameter is approximately $0.5: 1$.

Tangential sections show that the acanthopores, which on the surface appear to be of one size only, are really of two sizes and form a conspicuous feature. The zoœcial tubes are oral in section. The junction-angles contain a small cell which is also oval in section, and is still visible in slides cut a considerable depth below the surface. More numerous slides than it has been possible to prepare would be required in order to ascertain the true nature of these small cells. Those that have been observed in longitudinal sections are tabulated, but the tabulation does not appear to be different from that of the zoœcia proper.

Distribution.-The specimens on which this species is founded are from the Sandersdean Limestone of Sandersdean, $1 \frac{3}{4}$ miles S.S.E. of Haddington, near the top of the Calciferous Sandstone Series. 
Olservations. - The presence of small interstitial cells, possibly of the nature of mesopores, suggests that this species is not a true Stenopora, but since it has not yet been observed from other horizons its true aftinities cannot be established, and consequently it is here allocated to that genus for the sake of convenience only.

The specimen from which the slide figured pl. xv, figs. 3, 4, was marle is preserved in the collections of the Geological Survey in Scotland [N. $\left.308^{\mathrm{i}}\right]$.

\section{Stenopora dubia ( $\left.\mathrm{M}^{\circ} \mathrm{Coy}\right)$.}

Plate XV, fig. 8.

1844. Verticillopora dubia M[Coy. A Synopsis of the Characters of the Carboniferous Limestone Fossils of Ireland, p. 195, pl. xxvii, fig. 12.

Description.-(a.) External characters. The holotype consists of a hollow branch bearing two offshoots. The main branch is cylindrical, $48 \mathrm{~mm}$. in length and $6{ }^{\circ} \mathrm{m} \mathrm{mm}$. in width. It is split longitudinally and exposes the cast of the tube. The surface of the cast bears numerous oblique wrinkles, which show that the epizoarial membrane is wrinkled. The longitudinal fracture shows that the zoœcia are, in their proximal portion, short and inclined at an angle of some 45 degrees to the surface of the epizoarial membrane. Their distal portion is $1 \mathrm{~mm}$. long and at right angles to the surface. There are 40 zoœcia along a distance of $1 \mathrm{~cm}$. Very little of the surface is preserved. Where observable, the apertures are sub-polygonal, with narrow interspaces. The acanthopores appear to be of one kind only and are restricted to the junction-angles.

Of the two offshoots, the lower one is at right angles to the main branch and approximately of the same size. Its distal end is hollow and flattened, but near its junction with the main branch it appears to be solid. The other offshoot, which is presumably the original of the enlarged figure given by $\mathrm{M} \cdot \mathrm{Coy}$, is a small dichotomous branch the apex of which points towards the proximal end of the main branch. Whether it really grew downwards is not clear; it may be that it was partly displaced before fossilization took place.

As seen on M'Coy's figure, the branching form is accompanied, in the same specimen, by an incrusting zoarium enveloping the shell of an Aclisina. It is presumably an old zoarium, as its peripheral region attains a thickness of $1.5 \mathrm{~mm}$., which is greater than in the holotype.

(b.) Internal structure. A thin slice from the lower extremity of the holotype shows that the peripheral portion of the zoceia is closely tabulated. The thickening of the 
walls is not considerable, and was interrupted periodically at long intervals, so that the swellings are few and elongated. The axial portion had to be left unstudied, owing to lack of material. The original wall-substance is decomposed, having become white and amorphous ; in tangential section the walls appear structureless and the acanthopores are unrecognizahle.

Distribution.--The holotype is from the Lower Limestone of Cookstown, Ireland, and occurs in a red argillaceous limestone containing Foraminifera, a Rhynchonellid, a Productus allied to $P$. elegans $\mathrm{I}^{\circ} \mathrm{Coy}$, and a species of Aclisina.

At the time of writing, no other specimens referable to this species have come under notice.

Comparable species. - The tabulation of the peripheral region is a good diagnostic character. Of the species which in this respect resemble Stenopora dubia, the undescribed specimens from Lydstep Quarry [Pr. 3482-3, see p. 1.54] differ in having much thicker practically unbeaded walls and fewer tabulæ. In Stenopora castletonensis sp. nov., from the "Brachiopod-bed" of Treak Cliff, Castleton, Derbyshire, the tabule are fewer and the beading of the walls is closer, while the zoœcia are also much smaller.

Observations.-The type-specimen of Stenopora dubia is preserved in the Griffith Collection, National Museum of Ireland, Dublin. Grateful thanks are due to Dr. R. S. Scharff, without whose courteous help it could not have been possible to elucidate the systematic position of M'Coy's species.

\section{Stenopora castletonensis sp. nov. \\ Plate XV, figs. 9, 10.}

Description.--(a.) External characters. In the specimens that have come under observation the zoarium is composed of solid, cylindrical dichotomous branches 2 to $7 \mathrm{~mm}$. in diameter. The surface features are not shown. There are some fifty-five tubes along a distance of $1 \mathrm{~cm}$.

(b.) Internal structure. As seen in longitudinal sections, the proximal ends of the zoœcia are, as usual, thin-walled. At a point situated below the surface at a distance equal to one-fourth of the diameter, they suddenly assume the thick walls characteristic of the group, and a direction perpendicular to the surface. The thickening is periodically interrupted and the moniliform structure is characteristic, the inner beads being short and close, the outer ones long and tapering. The thickness of the walls is generally 
equal to about one-third of the diameter of the zoccial cavity. Tabulæ are very scarce; a few are dereloped in the outer portion of the peripheral region, very rarely elsewhere.

The ratio of axial region to diameter is equal to $0 \cdot 5: 1$.

Tangential sections show that a cell smaller than the average occasionally occurs in the junction-angles. The acanthopores are small. In shallow section about eight are seen round each zoœcium; in deep section they are fewer. They evince no tendency to a regular disposition according to size, but rather to an arrangement in two sets, the one deeper than the other, though of the same size.

Distribution.-- This species is so far known from one locality only, namely Treak Cliff, Castleton, Derbyshire, in beds of D 2 age (top of the Visean), approximately.

Observations.-The most characteristic feature of Stenopora castletonensis is the tenuity of the zowcia relatively to the size of the zoarium. This character distinguishes it from most of the other Stenoporcie that have come under observation. The only ones somewhat comparable in this respect are Stenopora obliqua sp. nov. and Stenopora tenuipora sp. nov., which are distinct in having still smaller zoceia and different wallstructure and tabulation.

The specimens on which the present species is founded were collected by Dr. T. F. sibly, who kindly presented them to the Geological Survey.

\section{Stenopora obliqua sp. nov. \\ Plates XIV, fig. 12 ; XV, fig. 5.}

Description.-(a.) External characters. The zoarium is composed of cylindrical branches 2 to $5 \mathrm{~mm}$. thick, which may exceed $12 \mathrm{~cm}$. in length. The branches are either hollow or solid, the two modes of growth co-existing in the same bed. The surface is not well shown in the specimens at hand, but it appears to be devoid of macula or monticules. There are some sixty apertures along a distance of $1 \mathrm{~cm}$. Fractured specimens show that the zoœcia curve gradually from the axial region to the surface, on which they fall at an acute angle.

(b.) Internal structure. As seen in longitudinal sections, the zoccia-walls are very thin in the axial region. In the peripheral region they reach a thickness equal to about two-thirds of the diameter of the zoœcial cavity. They show very little tendency to periodical cessations of thickening, but are often appreciably flexuous. Tabulie are scarce in the axial portion of the tubes, but numerous in the peripheral region and in the 22239 
portion immediately preceding it. There are some ten tabulæ to each tube, and the distance separating them is approximately equal to their own diameter.

In tangential sections the acanthopores are restricted to the junction-angles. In the specimens observed, their substance is not very different from that of the wall, consequently they are rather inconspicuous.

The ratio of axial region to diameter is equal to $0 \cdot 5: 1$.

Distribution.-Numerous specimens of this species were obtained by Mr. A. Macconochie from a sandy limestone exposed on the shore $2 \frac{1}{4}$ miles $W$. of the mouth of the River Nith, near Arbigland, Kirkcudbright. This limestone belongs to the Calciferous Sandstone Series, and is presumably of D1 age.

Comparable species.-The course of the zoncia, which is here gentle instead of bending at right angles as is usually the case, distinguishes this species from the majority of the other British Stenoporae. Of the species so far known, the only one exhibiting this character in a marked degree is Stenopora tenuipora sp. nov., which otherwise differs considerably, having smaller zoœcia characterised by their polygonal section. A certain amount of obliquity is shown in the zoœcia of Stenoprora haddingtonensis sp. nov., but, as already stated, the presence of mesopore-like cells suggests that the latter form may probably not be congeneric with the varions species described here as belonging to Stenopora. Attention might also be drawn here to the fact that the absence of sharp bending occurs also in the genus Tabulipora, e.g., Tabulipora vexfordensis sp. nov.

Observations.-That Stenopora obliqua is specifically distinct from the common Scotch "Chaetetes tumidus" was recognized by Dr. B. N. Peach who entered it as Stenopora arbuscula Eichwald, in the palæontological appendix to the Survey Memoir describing the geology of Kirkcudbright. ${ }^{1}$ But, although the species described here certainly does resemble Stenopora arlnuscula in its mode of growth, it is deemed safer to propose a new name for it, since Eichwald's species is an Upper Carboniferous one, the internal structure of which is imperfectly known. The slide figured pl. xv, fig. 5 was cut from a specimen labelled M. $3317^{\mathrm{b}}$, preserved in the collections of the Geological Survey in Scotland. 


\section{STENOPORA TENUIPORA sp. nov.}

Plates XIV, fig. $10 ; \mathrm{XV}$, figs. 6,7 .

Description.-(a.) External characters. In the single available specimen of this species the zoarium is composed of a solid cylindrical dichotomous branch $3 \mathrm{~mm}$. thick. The surface is even, there being neither maculæe nor monticules. The apertures, numbering some eighty along a distance of $1 \mathrm{~cm}$., have thin partitions, and are polygonal in outline. They are generally of sub-equal size, only a few being distinctly smaller than the average. An acanthopore occurs at most of the junction-angles. The fractured ends of the zoarium expose the casts of the zoccial tubes, which are seen to reach the surface at an acute angle, without a sharp bend.

(b.) Internal structure. In longitudinal sections the zoœcia-walls are seen to curve gently towards the surface. At a distance from the surface equal to about one-sixth of the diameter, they assume the usual thickening, which is not very considerable, the thickness of the wall being generally somewhat less than one-third of the diameter of the zoøcial cavity. The walls show no indications of beading, but they are markedly flexuous. Tabulæ are generally confined to the peripheral region where as a rule less than six are visible, separated by intervals which may be less than their own diameter. Very few tabulæ occur in the axial region. A peculiar feature observed in two of the sections prepared, is that in many instances the tabulæ appear to be much thicker proximally than distally. The ratio of axial region to diameter is equal to about $0 \cdot 7: 1$. Tangential sections exhibit clearly one of the most characteristic features of the species, namely, the polygonal shape of the zoœcial tubes, which, as already stater, is also shown by the apertures. A fairly large acanthopore, often with a distinct central lumen, generally occurs at the junction-angles. From this description it will be seen that the aspect of a tangential section is very much like that of the surface.

Distribution.-The specimen described here was collected by Dr. A. Vaughan from the basement beds (K1) of the Lower Carboniferous in the Avon section, Bristol. [Since the above passed into the press, specimens referable to the same species have been observed in a fragment of limestone from Hook Point, Wexford].

Comparable species.-The extreme tenuity and the polygonal shape of the apertures and zoœcia of Stenopora tenuipora distinguish it readily from the other Stenoporae described in this contribution. Flexuous walls and zoceia falling obliquely on the 22239

$\mathrm{D} 2$ 
surface are characters obtaining also in the previous species, from which it differs by the above noted features.

Observation.-The holotype is preserved in the collection of Dr. A. Vaughan, to whom grateful thanks are due for allowing sections to be made from it.

\section{Genus Tabulipora Young. ${ }^{1}$}

Section A :-Species in which the perforation of the tabulæ occupies a central or subcentral position

Tabulipora scotica sp. nov.

Plates XIV, figs. 4 A-4 D ; XV, figs. 12, 13, 17, 18.

Description.-(a.) External characters. The zoarium consists of solid cylindrical dichotomous branches from 2 to $7 \mathrm{~mm}$. in diameter. There are some forty apertures along a distance of $1 \mathrm{~cm}$. Their partitions are rather thin and somewhat raised, and their outline sub-polygonal. A cell smaller than the average occurs sometimes between the larger ones. With a strong lens an acanthopore can be seen at each of the junction-angles. There are no monticules, but maculæ of smali cells are common.

(b.) Inernal structure. Longitudinal and transverse sections show that the peripheral, thick-walled portion of the zoøcia is at right angles to the surface. The walls, which as usual are very thin in the axial region, are in the peripheral region about half as thick as the diameter of the zoœcial cavity. Usually they exhibit a distinct moniliform structure, there being as a rule some four or five swellings ; but certain specimens not unfrequently evince a decided tendency towards the formation of uniform walls, both beaded and unbeaded walls co-existing in the same section. The tabula bear a central perforation the shape of which is somewhat reniform. The margin of the perforation is usually raised proximally, appearing in section as a short projection pointing downwards. The size of the perforation is equal to about one-third of the diameter of the tabula. The ratio of axial region to diameter is equal to $0 \cdot 6: 1$.

In tangential sections a small acanthopore can generally be seen at the junctionangles. Besides, there are often numerous small dark spots, irregular in outline, arranged either in sporadic groups or in straight lines. A black line, which may be due to the merging of these black spots, sometimes occurs between adjoining zoœcia.

\footnotetext{
${ }^{1}$ A description of the genus is given on p. 149.
} 
The zoœcia have a circular or sub-circular section : the sub-polygonal aspect of their apertures is therefore a superficial character.

Distribution.-Tabulipora scotica is a wide-spread fossil throughout the Lower Limestone Series of Central Scotland. Though not a rock-forming organism, it seldom fails to be present whenever the rock was deposited under truly marine conditions. In the Upper Limestones the conditions which generally were adverse to many of the organisms which flourished in the Lower Limestones, were especially unfavourable to the Trcpostomata: undoubted specimens of Tabulipora scotica are so far known from two Upper Limestone localities, namely Garpel Water near Muirkirk, and Brunston Castle near Pennycuick, Midlothian. It appears to be rather rare in England. It is found in the Six Yards Limestone of Little Mill, Northumberland [J. R. 4721], and an imperfectly preserved specimen possibly belonging to it was collected at Brunton Quarry, half a mile S.E. of Chollerford Station, Northumberland, presumably from the Great Limestone [25576]. Tabulipora scotica has not yet been observed from the Midlands and the South-West Province, nor, in the North-British area, from beds lower than the top of the Visean.

Comparable species.-Small specimens of Tabulipora howsei (Nich.) bear a general resemblance to Tabulipora scotica, but in the former the ratio of axial region to diameter is smaller, being $0.5: 1$ instead of $0.6: 1$, and the swellings of the walls are more numerous and separated by deeper constrictions. From the Dun Quarry, Northumberland, Mr. J. Rhodes collected a specimen of a Tabulipora [25570], which in its general aspect suggests Tabulipora scotica, but differs from it in having much thicker walls, in which the constrictions are also fewer.

Observations.-The sections figured in pl. xv, figs. 12 and 18, are preserved in the Collections of the Geological Survey in Scotland, in Edinburgh. Fig. 13 is from a slide belonging to the Young Collection, Kelvingrove Museum, Glasgow, labelled Tabulipora urei (Flem.), Hillhead Quarry, Beith $\left[\begin{array}{c}01-53 \\ \mathrm{~b} \times \mathrm{s}\end{array}\right]$. It might be stated here that the Young Collection contains more than one species, the relationships of which are discussed on p. 165.

Other specimens are preserved in the Nicholson Collection, Aberdeen University ; the Neilson Collection, Royal Scottish Museum, Edinburgh; and in the collections of Messrs. R. Dunlop and J. Wright. 


\section{TABUlipora youngi sp. nov.}

Plate XV, figs. 19, 20.

Description.-(a.) External characters. The zoarium consists of solid cylindrical branches from 2 to $6 \mathrm{~mm}$. in diameter. About forty sub-polygonal or sub-circular apertures are found along a distance of $1 \mathrm{~cm}$. Specimens which agree in their internal structure show differences in the thickness of the partitions of the apertures, which tend to be circular, the thicker their partitions. In the forms with thick partitions some ten small acanthopores encircle the aperture.

(b.) Internal structure. In the peripheral region the diameter of the walls is approximately equal to that of the zoccia, and is uniform throughout. Some five tabulæ, with reniform central perforation, generally occur in the peripheral region, where the distance separating them is approximately equal to their own diameter. Tabulæ are scarce in the axial region. The ratio of axial region to diameter is about $0 \cdot 5: 1$. Tangential sections show that the acanthopores are not so regularly distributed as one might infer from the surface characters. Numerous dot-like acanthopores(?) occur between a larger set generally localised in the junction-angles.

Distribution.-Tabulipora youngi has been found at a number of Scottish Lower Limestone localities. It is not yet known from other horizons or from localities outside Central Scotland.

Observations.-The sections figured in pl. xv., figs. 19, 20, belong to a slide preserved in the Young Collection, Kelvingrove Museum, Glasgow, labelled $\left[\begin{array}{cc}01 & -53 \\ \mathrm{~b} & \mathrm{x} \mathrm{r}\end{array}\right]$ with the name Tabulipora urei (Flem.).

The ratio of axial region to diameter, and the considerable thickness of the walls, readily separate $T$. youngi from other Scottish species.

\section{Tabulipora minima sp. nov.$$
\text { Plate XV, fig. } 21 .
$$

Description.-(a.) External characters. The zoarium consists of small solid cylindrical branches from 1 to $2 \mathrm{~mm}$. in diameter. As this species is usually indifferently preserved it is not possible to state whether macule and monticules are present. There are about forty apertures along a distance of $1 \mathrm{~cm}$. Both circular and subpentagonal apertures can be seen on the same zoarium. A row of minute acanthopores can just be seen with the help of a strong lens. 
(b.) Internal structure. In most instances the thick-walled peripheral end of the zoœcia is not at right angles to the surface, but falls on it somewhat obliquely. The thickness of the peripheral end of the walls is approximately equal to one-third of the diameter of an average zoœcium. Perforated tabulæ are present throughout the course of the zoccia, but are more abundant in the peripheral and sub-peripheral regions, where the distance separating them is usually less than their own diameter. They are thick, with a well marked proximally raised margin round the perforation. The ratio of axial region to diameter is $0 \cdot 6: 1$. Tangential sections show a moderately large acanthopore at most of the junction-angles. Besides, in shallow sections, adjoining zonecia are separated by a row of minute black dots, which, when close together, appear as a black line.

Distribution.-Small branches presumably belonging to this species are often found in the Scottish Lower Limestones, but since they are usually too imperfectly preserved to permit of correct identification, it is advisable to mention here only the locality from which tolerably good specimens were obtained, namely, Howood Quarry, Renfrewshire.

Observations. - The materials on which the above description is based are represented by seventy-eight sections on three slides preserved in the Young Collection and labelled

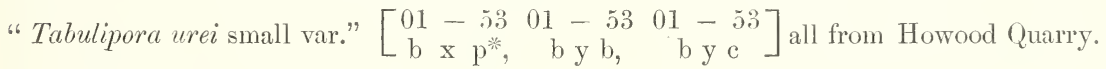
The section figured in pl. xv., fig. 2l, belongs to the last of these slides.

\section{Note on the Trepostomata of Central Scotland.}

Besides the three species described above, the Young Collection contains a fourth, to which a separate description is not allotted here, since it seems to be very rare. It is depicted in pl. xr., fig. 11, and the original is one of eight sections on a slide $\left[\begin{array}{cc}01 & -53 \\ b & x\end{array}\right]$ labelled, like the preceding species, with the name Tabulipora urei (Flem.). The locality is Trearne, Beith, Lower Limestones. The specimen has an oval section, but this is not due to crushing. The centre is obscured by infiltrated matter, and has been left blank in the figure. The chief distinguishing characters of this species are the small proportion of the axial region relatively to the diameter, and the slender walls and close tabulation of the zoccia in the peripheral region. A specimen [25572] resembling this one in its proportions, but differing in having less distinctly beaded walls, was obtained by Mr. Rhodes from an old quarry N.E. of Bowsden, $1 \frac{3}{4}$ miles N.W. of Lowick, Northumberland (see pl. xiv., fig. 6). With so little material at hand it is not possible to say whether 
this form is to be regarded as an offshoot from the common Tabulipora scutica or as a mutation of Tabulipora howsei (Nich.).

Furthermore, materials, unfortunately insufficient for close study, show that a genus possessing mesopores is also present in the Lower Limestones of the East Kilbride district. Assuming that the specific distinctions made here are justified, it follows that at least five species of Trepostomatous Bryozoa oceur in the East Kilbride region. And, since Ure's "Millepore" came from that district, Young's view that any specimen could be regarded as a topotype cannot be upheld, nor can his proposal to revive its first Linnean name, Cellepora urei Flem., be adopted, ${ }^{1}$ the original of Ure's " Millepore" being lost.

Regarding the mutual relationships of the three species Tabulipora scotica, T. youngi and $T$. minima, little ean be said, since they are all from the same horizon and their progenitors in lower deposits cannot be traced. Howerer, as they occur in the same sediments, it does not seem probable that they represent different conditions of the same organism. T. scotica evinces a tendency to the loss of moniliform structure, but the total loss of this feature would not suffice to evolve an organism undistinguishable from $T$. youngi, in which the peripheral portion of the walls is thicker and longer. T. minima has been compared with equal-sized specimens of the two other species, and its. distinguishing characters have been found to hold good; it cannot, therefore, represent small branches of either.

\section{Tabulipora howsei (Nicholson). \\ Plates XIV, figs. $9 \mathrm{~A}-9 \mathrm{C}$; XV, figs. 22-24.}

1881. Stenopora Ilowsii Nicholson. On the Structure and Affinities of the Genus Monticulipora and its Subgenera, pp. 82, 83.

1883. Stenopora Howsii Nicholson. Contributions to Micro-Palæontology. On Stenopora Howsii, Nich., with Notes on Monticulipora? tumida, Phill., and Remarks on Tabulipora Urii, Ioung. Ann. Mag. Nat. Hist., vol. xii., Fifth Series, p. 285, pl. x.

Description.-(a.) External characters. The zoarium consists of hollow or solid branches, cylindrical or oval in section, from 5 to $20 \mathrm{~mm}$. in diameter. Complete colonies have not come under observation, but the thickest yet seen very likely exceeded $20 \mathrm{~cm}$. in length. The branching is dichotomous alternate. The hollow and solid modes of 
growth often co-exist in the same branch, apparently without obeying any definite order of succession. There are 40 apertures along a distance of $1 \mathrm{~cm}$. 'They are as a rule sub-polygonal, their partitions being generally thin, but sometimes they are sub-circular, when the margins are thicker. An acanthopore can generally be seen at the junctionangles. Macula of small thick-walled cells are common.

(b.) Internal structure. Longitudinal sections are highly characteristic: the peripheral end of the walls is typically moniliform. The swellings are very numerousnumbering up to 20 in large specimens-and are separated by pronounced constrictions. The tabulice are few in the axial region, but numerous in the peripheral region, where they are close-set, being separated by intervals which can be less than their own diameter. They bear a central reniform perforation, which is bordered by a raised rim pointing towards the proximal end of the tubes. In some instances the perforation is covered by a convex plate, also situated on its inner or proximal side. Two of these peculiar bodies are shown in the first and fifth tubes from the top, pl. xv., fig. 22. The ratio of axial region to diameter is $0 \cdot 5: 1$ in cylindrical branches.

Tangential sections show two sets of acanthopores: comparatively large ones are deep seated, and are restricted to the junction-angles, while a dozen small ones encircle the zoccia in shallow sections.

The reniform shape of the perforation of the tabulæ is well shown on a polished section belonging to the Nicholson Collection, where it can be seen that the perforation is not orientated in any definite direction.

Distribution.-The holotype-and many paratypes preserved in the Nicholson Collection-are from Redesdale, Northumberland, presumably from the shale associated with the Ironstone, where both the hollow and solid forms co-exist. Small specimens referable to $T$. howsei were collected by $\mathrm{Mr}$. J. Rhodes, 1 mile E. of Waterhead [R. 3431]; at Hirsthead Sike, Liddel Water, Cumberland [R. 3278]; and at Chatton Quarry, Chatton Noor, Northumberland [R. 4586], the last being from the Woodend Limestone, presumably. In scotland large examples were obtained from the top of the Calciferous Sandstone at Arbigland, Kirkeudbrightshire, and from the position of the Lawston Linn Limestone, a quarter of a mile N.W. of Gilnockie Tower, Dumfriesshire. It is interesting to note that the above localities may in a broad way be said to hie on the same horizon, approximately near the middle of the Visean. Remarkably large examples were collected from a black limestone-probably the Poolvash Limestone-at Port St. Mary, Isle of Man, by Messrs. J. Smith, R. Dunlop and J. Wright. Another 
specimen from the Isle of Man is preserved in the Sedgwick Museum, Cambridge [No. 300].

Quite typical examples of Tabulipora housei occur in the Carboniferous rocks of Ireland. The Collection of the Geological Survey of Ireland contains a specimen preserved in black shale, with the indication : Tyrone, Clogher, agreeing closely with Portlock's Favosites tumida ${ }^{1}$ which is also from that locality. More precise indications regarding its horizon are afforded by materials collected by $\mathrm{Mr}$. WV. B. Wright in the Bundoran district, where T. howsei occurs in the Upper Calp Shales, accompanied by a variant in which the proportional size of axial region to diameter is greater than in the typical form.

Fully developed specimens of T. housei are such striking objects that they could not possibly be overlooked by collectors. It may thus be safely assumed that the species does not occur in Central and South-Western England, conditions suitable to its development having restricted it to the North-British area, the Isle of Man and Northern Ireland.

Comparable species.-The large size that $T$. housei attains when developed under favourable conditions distinguishes it at first sight from all the other British Trepostomatous Bryozoa. The smaller examples are distinguished from $T$. scotica by the more pronouncer beading of their walls and the smaller proportions of the axial region. The presence in the East Kilbride district of a small form with similar wall-structure, but with much narrower axial region, has already been noted. A specimen 'collected by Mr. J. Ingram from a loose block of limestone near Sattle, has similar proportions, but indistinct beading.

A specimen preserved in the Collections of the Geological survey of Ireland [1989 from the Lower Limestone of Gibbonstown, Limerick, appears to be closely related to T. housei, from which it differs mainly in having thicker walls. This is the only record of a centrally perforated Tabulipora from Tournaisian beds.

Species bearing a strong resemblance to $T$. howsei occur outside Britain. T. aretica (Nich.) [Stenopora howsii, var. arctica Auct.] ${ }^{2}$ from the Upper Carboniferous rocks of Feilden Isthmus, Lat. $82^{\circ} 43^{\prime} \mathrm{N}$., differs mainly in having slightly smaller zoœcia. The American fauna contains two species agreeing with T. howsei in the pronounced beading of the walls, namely $T$. anericana (Ulrich) and $T$. conferta (Worthen). The first of these agrees closely, differing only in the slightly larger size of the zoceia and the more 
nearly circular shape of the perforation ; the other differs by the same characters, and in having stronger acanthopores.

Nicholson's species is mentioned by Romanowski, who appears-the text is in Russian-to compare it with his stenopora lahuseni, which it certainly resembles in its mode of growth and strongly beaded walls. But the Russian species is depicted as having complete tabula. ${ }^{1}$

Observations. - T. howsei has sometimes been recorded as Wonticulipora inflata de Koninck. That there are good grounds for considering the latter to be very distinct from the former, is shown on p. 183.

The specimen figured, pl. xv., figs. 22-24, was collected by Mr. A. Macconochie on the left bank of the River Esk, a quarter of a mile N.W. of Gilnockie Tower, Dumfriesshire, from a bed situated at the horizon of the Lawston Limn Limestone [M. $648^{\circledR}$ ].

\section{Tabulipora tenumuralis sp. nov.}

Plate XV, figs. 25-27.

Description.-(a.) External characters. The zoarium is composed of hollow or solid branches from 5 to $10 \mathrm{~nm}$. in diameter. Some forty-five apertures occur along a distance of $1 \mathrm{~cm}$. They have thin partitions and are markedly polygonal in outline. Maculæ of small cells are surrounded by apertures larger than the average. A small acanthopore occupying the junction-angles can be made out with the help of a strong lens.

(b.) Internal structure. The peripheral end of the walls is at right angles to the surface. The walls, though showing moniliform structure, are remarkably thin. They are flexuous and sometimes appear as if anastomosed. The tabule are close-set, generally less than their diameter apart. The perforation is not so nearly central as in the preceding species, but somewhat sub-central, and appears to be circular. The ratio of axial region to diameter, in the solid form, is $0.5: 1$.

Seen in tangential sections, the zoœcia have a polygonal outline. The acanthopores, moderately large, are all of the same size and generally occupy the junction-angles, occurring rarely elsewhere.

Distribution.-A few specimens of the hollow form of this species, from Ravenstonedale, are preserved in the Nicholson Collection. A solid specimen was collected by Mr. Rhodes at the Eelwell Quarry, near Lowick, which is referred to the D 2 zone. 
Comparable species.-The tenuity of the peripheral end of the walls is a character which occurs in one only of the other known species of Section A of Tabulipora, namely T. nueandria sp. nov., a species agreeing closely in its internal structure, but exhibiting a most unusual mode of growth.

Observations.-The sections figured, pl. xv., figs. 26, 27, are from one of the Ravenstonedale specimens in the Nicholson Collection, while fig. 25 is from the Lowick specimen [25571], preserved in the Collections of the Geological Survey in London.

\section{TABUlipora maeandria sp. nov.}

\section{Plate XV, figs. 28, 29.}

Deseription.-(a.) External characters. The type consists of an irregular mass, $40 \mathrm{~mm}$. long, some $25 \mathrm{~mm}$. in width, and $13 \mathrm{~mm}$. thick, composed of zoccia attached to an epizoarium which is repeatedly folded upon itself. Where the lower surface of the epizoarium is exposed, it is seen to be wrinkled.

(b.) Internal characters. The proximal end of the zoocia is nearly parallel to the epizoarium, the distal end being at right angles. The wails are thin throughout, with a few slender, but distinct swellings in the distal region, which attains $5 \mathrm{~mm}$. in length. Owing to the thinness of the walls, the zoœcia have a polygonal section. The tabulæ are separated by intervals which can be less than their own diameter, and bear a small subcentral perforation. A small acanthopore can be seen at the junction-angles. There are some forty-five zoœcia along a distance of $1 \mathrm{~cm}$.

Distribution.-The type, and two or three specimens probably conspecific with it, were collected by Mr. J. Smith from the white limestone of Poolvash, Isle of Man.

Comparable species. - The similarity between the internal structure of Tabulipora tenuimuralis and that of T. maeandria has already been noted. Were future investigations to disclose the existence of the former as offshoots attached to the latter, then the two species could be united, if the peripheral region of $T$. teruimuralis were shown to attain the length it has in T. maeandria. An analogous mode of growth is exhibited in a specimen preserved in the Collections of the Geological Survey of Ireland. It is fragmentary, but judging from its shape, it must have belonged to a mass of considerable size, not unlike Stenopora crinita Lonsdale, as figured by Mr. R. Etheridge. ${ }^{1}$ The zoœcia are much larger than in T. maeandria, and the appearance of the casts seems to show 


$$
\text { G. W. Lee-Trepostomata. }
$$

that the walls were more elosely beaded. The nature of the tabulation could not be studied. This specimen is from Donaghenry, Tyrone (Upper Limestones), and is probably the form referred to Favosites filrosa by Portlock. ${ }^{1}$

Observations.-The above description had to be drawn up partly from the examination of polished surfaces, the extreme brittleness of the specimen precluding the possibility of making satisfactory slicles.

\section{Genus Tabulipora Young.}

Section B:- Species in which the perforation of the tabula occupies a lateral position, distal in relation to the general direction of growth.

Tabulipora sparsitabulata sp. nov.

$$
=\frac{\text { Stenophragma Murre }}{\text { See Munrd }(912, p .577 .}
$$

Plates XIV, fig. 7 ; XV, fig. 31 ; XVI, fig. 1.

Description.-(a.) External characters. In the examples that have come under observation the zoarium is hollow, and attains a thickness of $15 \mathrm{~mm}$. There are from forty to fifty polygonal apertures along a distance of $1 \mathrm{~cm}$. Cluster' of cells smaller than the average occasionally occur. An inconspicuous acanthopore can be made out at the junction-angles, with the help of a strong lens.

(b.) Internal structure. The proximal portion of the walls is short and forms a variable angle with the epizoarium. The peripheral part is long, and at right angles to the direction of growth of the zoarium, and shows distinct moniliform structure. The thickening is more considerable than one would infer from the aspect of the apertures. The tabula are scanty, numbering at most fire to each tube, across which they extend only partly, leaving an untabulated space, which is always situated on the distal side of the tube, relatively to the direction of growth of the colony.

Seen in tangential sections, the zoccia have a circular outline. Simall, but deepseated acanthopores are localised at the junction-angles, while a row of black dots, possibly of the nature of acanthopores, occasionally encircles the zoccia as seen in shallow sections.

Distributiou.-The specimen taken as the type was collecter by Mr. J. Rhodes in the bed of a streamlet E. of Wood Park, $1 \frac{5}{x}$ miles N.N.W. of Wark Parish Church, Northumberland [25.578]. T. sparsitabulata occurs also, in the same county, at Barmoor Redhouse Quarry, $1 \frac{1}{4}$ miles S.W. of Lowick [25.573]; at the Woodend

$$
{ }^{1} 33, \text { p. } 327 .
$$


Quarry, $3 \frac{1}{4}$ miles $W^{T} . \mathrm{N} . W$. of Lowick $[25574]$; at a quarry three-eighths of a mile N.E. of the Demesne, Gunnerton [25577]; and somewhat doubtfully at Closehead Old Lime Quarry, three-quarters of a mile E. of Otterburn Church [25575]. In Cnmberland, it was collected from the bed of a streamlet at Longclenchside, and at Hirsthear Sike, Liddel Water [R. 3043, R. 3237]. In Scotland, it occurs at Lawston Limn. All these localities seem to be close to each other in stratigraphical position, which in the main may be assigned to the D 1 zone of the Visean.

From the Irish fauna a few examples of Tabuliporu have come under observation, which present the same general characters as $T$. sparsitalulata and yet show certain differences of apparently secondary importance. The illustrations given in pl. xr., fig. 30, and pl. xri., fig. 2, are from a specimen from Tyrone-the precise locality is not known-preserved in the Collections of the Geological Survey of Ireland. At first sight the close beading of the walls might determine is allocation to a distinct species. As, however, a specimen collected by Mr. W. B. Wright at Kinlough, Bundoran (Upper Calp Shale), shows the co-existence of both close and wide beading within the same zoarium, the Irish representatives may tentatively be placed here until the taxonomic value of this varietal character can be better estimated.

In the South-West Province specimens of this species were collected by

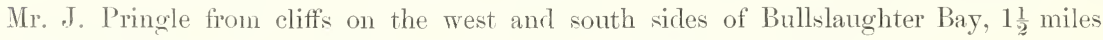
W.S.W. of Bosherston. The horizon is D1 [Pg. 1964, Pg. 2078].

Observations.-Considerable difficulty was experienced in separating this species and the next from several forms into which they appear to merge. Owing to the insufficiency of materials it is not possible to ascertain the degree of relationship of these apparently allied forms, which are discussed more fully in the observations on the next specier.

\section{Tabulipora crassmuralis sp. nor. \\ Plates XIV, fig. 8 ; XVI, figs. .̌, 6.}

Description.-(a.) External characters. In the materials at hand the zoarium is hollow, from 3 to $12 \mathrm{~mm}$. thick, cylindrical or flattened. The shape of the apertures varies from sub-oval to sub-polygonal. They have generally thick partitions, and number about forty along a distance of $1 \mathrm{~cm}$. Small acanthopores can be seen by means of a lens. 
(b.) Internal structure. The peripheral part of the zoxcia is short and somewhat oblique relatively to the long axis of the zoarium. In that portion of their course the walls are very thick. In the type-specimen they do not show moniliform structure.

The tabulæ are scarce-at most five to each zoœcium - and extend only half-way across the cavity. Tangential sections near the surface show that the acanthopores are of two sizes: larger ones occupy the junction-angles while numerous minute ones encircle the zoœcia.

Distribution. - The original of pl. xvi., figs. 5 and 6, was collected by Mr. E. Dixon 150 yards S.E. of Stackpole Quay Farm, Stackpole, from beds belonging probably to the C zone of the Lower Carboniferous [E. D. 998]. A specimen differing from the type in having shightly moniliform walls, was found at Blucks Pool, S. end of Freshwater West, Pembrokeshire, in beds belonging to the top portion of the Tournaisian [E. D. 1750].

Comparable species. - The last mentioned specimen seems to be intermediate between the type and two forms in which the peripheral end of the walls is thinner and more distinctly moniliform, thus suggesting affinities to $T$. sparsiabuicata. One of these [E. D. 995] occurs with the type at Stackpole; the other comes from The ITash, Castlemartin, and belongs probably to the Syringothyris Zone.

A specimen collected on the English side of Penton Bridge, Cumberland, from a bed characterised by the typical form of Productus yiqanteus (Mart.), has, like T. crassinumalis, thick unbeaded walls, but the peripheral end of the tubes being longer it may equally well be considered as bearing affinities to T. sparsitabulata.

\section{Tabulipora multitabulata sp. nov.}

$$
\text { Plate XVI, figs. 3, } 4 \text {. }
$$

Description.-(a.) External characters. In the specimens that have come under observation, the zoarium consists of solid cylindrical dichotomous branches from 4 to $7 \mathrm{~mm}$. thick. The apertures number about 60 along a distance of $1 \mathrm{~cm}$. Their outline is circular and the partitions are rather thick. An aperture smaller than the average is frequently interpolated between the main ones. By means of a strong lens a row of acanthopores can be seen encircling the zoœcia.

(b.) Internal structure. The peripheral part of the zoceia is long and at right angles to the long axis of the zoarium. In that portion of their course the walls are as thick as, or thicker than the diameter of the enclosed zoœcial cavity, and afford a slight suggestion of moniliform structure. 
The tabule are scarce in the axial region and numerous in the peripheral region, where they are less than a zoceial diameter apart and may number up to ten or more. They extend half way across the cavity.

The smaller cells exhibit the same features as the larger ones, and are therefore probably not of the nature of mesopores.

The ratio of axial region to diameter is $0 \cdot 5: 1$. Tangential sections show the presence of two sets of acanthopores. The larger ones, occasionally showing a central lumen, are restricter to the junction-angles, while as many as ten of the smaller ones encircle the zoocia.

l)istribution.-A specimen of highly crinoidal limestone contains several fragments of this species [Rh. 2247]. It was collected by Mr. J. Rhodes three-quarters of a mile E.N.E. of Stockdale Farm house, in the Settle district. T. multitalualatı has not been found to occur elsewhere.

Observations.-The smail, closely tabulated zoocia of this species distinguish it readily from the other members of the group described in this contribution.

\section{TABULIPORA WEXFordensis sp. nov.}

Plates XIV, fig. 13 ; XVI, fig. 7.

Description.-(a.) External characters. The type and only known specimen consists of a solid cylindrical zoarium $4 \mathrm{~mm}$. thick, branching dichotomously. The apertures, of which there are some fifty along a distance of $1 \mathrm{~cm}$., are sub-polygonal in outline, their partitions being generally thin. A strong lens shows the presence of an acanthopore at the junction-angles. Transverse fractures show that the peripheral end of the zoceia is not at right angles to the surface, but falls on it obliquely.

(b.) Internal structure. The thickness of the walls at the peripheral end is usually equal to less than half the diameter of an average zoocium. In that portion of their course the ralls have from two to three swellings separated by shallow constrictions.

'The tabulae are scarce in the axial region, but more numerous in the peripheral end of the zoøcia, where they can be occasionally much less than a zoœcial diameter apart. The ratio of axial region to diameter is $0 \cdot 6: 1$. Seen in tangential sections, the zoecia are circular or sub-oval, not sub-polygonal as might be inferred from the aspect of their apertures. The acanthopores are small, and sporadically developed at the junction-angles.

Distribution.-T. wexfordensis is so far known from one locality only, namely, Hook, Wexford, Ireland ; that is, from a bed of Tournaisian age presumably. 
Comparable species.-Of the other Tabuliporae with laterally perforate tabulæ, the only one to share with $T$. wexfordensis the character of having zoccia falling obliquely on the surface, is $T$. crassimuralis, whose thick walls afford a ready distinguishing feature.

Observation.-The original of pl. xvi., fig. 7, is preserved in the Collections of the Geological Survey of Ireland.

\section{Tabulipora debilis sp. nov. \\ Plate XVI, fig. 8 .}

Description.-(a.) External characters. In the two specimens that have come to hand the zoarium is hollow and tapers appreciably, the diameter being $1 \mathrm{~cm}$. near the base of the zoarium, and only $8 \mathrm{~mm}$. above the base. The surface is not shown.

(b.) Internal structure. The zoœcia- of which there are some forty along a distance of $1 \mathrm{~cm}$.- - are attached to the epizoarium along a very small portion of their course and soon assume a direction perpendicular to the long axis of the zoarium. The walls are hardly thicker in their peripheral portion than in the axial region.

The tabulse are somewhat more than a zoccial diameter apart and extend only partly across the cavity.

In tangential section the extreme thinness of the walls is well shown, the zoøcia having consequently a polygonal outline. Acanthopores occur at the junctionangles only.

Distribution.-The illustration is from one of two specimens in the Nicholson Collection, which are from Stebden Hill, Cracoe, near Skipton, Yorkshire.

Observations.--Nicholson labelled these two specimens ef. Verticillopora dubia $\mathrm{M}^{6} \mathrm{Coy}$. From the above description it will be seen that the resemblance is merely one of zoarial shape.

The remarkable thinness of the walls distinguishes this species from all the other members of the group described here.

\section{TABUlipora spe.}

Two forms too insufficiently represented to warrant a separate description may be recorded here. Both belong to Section B of Tabulipora, which thus appears to be the richest in species in the British Carboniferous rocks. 
Specimen R. 2749, from near Kirk Beck, Cumberland, is a small solid branch, characterised by a short peripheral region and the scarcity of the tabulæ.

From the Upper Calp Shale of Bundoran, Ireland, Mr. W. B. Wright collected a Tabulipora remarkable by the extreme minuteness of the zoœcia, of which seventy occur along a distance of $1 \mathrm{~cm}$. The peripheral region is long. The tabula are more abundant in the portion preceding the final bending than in the peripheral region. The walls are irregularly moniliform and acanthopores are absent. The ratio of axial region to diameter is $0.5: 1$.

\section{Genus Batostomelia Ulrich. ${ }^{1}$}

Batostomella bundokensis sp. nov.

Plate XVI, figs. $16,17$.

Description.-(a.) External characters. The type consists of a solid, regularly cylindical branch $5 \mathrm{~mm}$. thick. The surface appears smooth to the naked eye. By means of a strong lens, the zoccial apertures, of which there are some sixty along a distance of $1 \mathrm{~cm}$., are seen to be surrounded by numerous smaller apertures. Both are sub-circular. The acanthopores are not readily seen. Macula or monticules appear to be absent.

(b.) Internal structure. Vertical sections show that the axial region is narrow, and the bend to the periphery abrupt and at right angles, while the thickening of the walls is considerable, assuming sometimes a roughly moniliform structure. Each zoœcium is accompanicd by a variable but considerable number of mesopores. The tabula are very thin and are present at irregular intervals, it being quite possible that, owing to their thinness, they escape observation when the slide is ground to the usual thickness. In the portion of the slide selected for the drawing reproduced in pl. xvi., fig. 17, the tabulæ of the zoccium appear as centrally perforated, while those of the mesopores are complete except for interruptions probably attributable to tearing off during the process of grinding the slide.

In tangential sections the zoccia and the mesopores have a circular outline. The acanthopores are much larger than appears at the surface. They occur principally at the junction-angles of the mesopores, while smaller ones are occasionally seen round the zoœcia.

The ratio of axial region to diameter is $0 \cdot 5: 1$. 
Distribution.-The original of pl. xvi., figs. 16, 17, was collected by Mr. W. B. Wright, from the Upper Calp Shale of Bundoran, Ireland. This is the only locality in the British Isles at which a Carboniferous Batostomella has so far been found.

Comparable species.-The arrangement of the tabula and acanthopores shows some resemblance to that of the American Batostomella spinulosa Ulrich, which differs in having larger zoœcia and a shorter peripheral region. ${ }^{1}$ Longitudinal sections of $B$. bundorensis might, when the tabula are not shown, easily be confounded with sections of certain of the species classed here as Dyscritella; but the latter have angular mesopores, and tangential sections will show the difference.

\section{Genus Leioclema Ulrich. ${ }^{2}$}

Leioclema aVonense sp. nov.

Plate XIV, figs. 14-16.

Description.-(a.) External characters. In the specimens examined the zoarium is composed of solid cylindrical branches attaining a thickness of $22 \mathrm{~mm}$. The apertures of the zoœcia are separated by interspaces so thin that their outline is consequently polygonal; some thirty occur along a distance of $1 \mathrm{~cm}$. The mesopores are angular and rather irregularly distributed. The condition of the surface is such that the external characters of the acanthopores cannot be determined. It is also not possible to say whether maculie or monticules are present, but neither occurs in the small portion of surface available for study.

(b.) Internal structure. The zoœcia are longitudinal in the axial region. By a rather gentle turn they assume a radial direction, but without evincing any appreciable thickening of their walls, most of the inter-zoœcial space being occupied by the mesopores. The tabula are scarce and irregularly distributed in the zoœcia. They are much more abundant in the mesopores, though not crowded, being generally more than their diameter apart. In both sets of tubes they are always complete, and much stouter than in the majority of the species of Trepostomata noticed in this contribution.

Owing to the absence of a sharp change of direction in the course of the tubes, it is not possible to determine exactly the ratio of axial region to diameter. It probably oscillates between $0 \cdot 5: 1$ and $0 \cdot 6: 1$.

${ }^{1} 42$, pl. lxxv., fig. 1.

22239
${ }^{2}$ A diagnosis of the genus is given on p. 151.

F 2 
The acanthopores are conspicuous. They occur generally at the junction-angles, and owing to the thinness of the walls project into the cavities of the zoœcia and mesopores. Their centre does not show a lumen, but is much darker than the peripheral portions.

Tangential sections show that the mesopores do not form more than a single row between the zoœcia, and occasionally the zoœcia are in juxtaposition without any mesopores intervening.

Distribution.-The above description is based on the examination of several specimens discovered by Prof. S. Reynolds, of Bristol, and kindly lent by Dr. T. F. Sibly. They are from the basement beds ( $\mathrm{K} 1$ zone) of the Carboniferous rocks of the Avon section, and occur with Cleistopora and Productus bassus Vanghan. ${ }^{1}$ This species has not so far been met with from other localities.

Observations.-Leioclema avonense is the only British Carboniferous species of Leioclema yet found, and does not appear to be closely related to any of the numerous American species of this genus.

It is interesting to note that-so far as ascertained-the size of the present species is apparently greatly in excess of that generally attained by the other members of the genus.

\section{Genus Dyscritella Girty. ${ }^{2}$ \\ Dyscritella miliaria (Nicholson). \\ Plate XVI, figs 9, 10.}

1881. Monticulipora tumida, var. miliaria Nicholson. The Genus Monticulipora and its Sub-Genera, p. 123, pl. iii., fig. 2.

Description.-(a.) External characters. The zoarium consists of solid cylindrical branches from 2 to $4.5 \mathrm{~mm}$. thick. Some forty-five zoœcial apertures occur along a distance of $1 \mathrm{~cm}$. Their outline is circular. They are never in contact, being separated by a variable number of minute sub-angular mesopores. Nacula of mesopores are not uncommon. The acanthopores cannot be seen, even with a strong lens.

(b.) Internal structure. The peripheral portion of the zoccia-walls is greatly thickened and at right angles to the long axis of the zoarium. The most conspicuous feature of longitudinal sections is the large number of mesopores, which appear as

\footnotetext{
${ }^{1}$ From information kindly supplied by Dr. Sibly.

2 A diagnosis of the genus is given on p. 151.
} 
digitations of the main walls. They are generally shallow, few reaching the bend preceding the final change of direction of the walls. In some portions of the slide figured in pl. xvi., fig. 10, they are seen to deviate from their general direction shortly after leaving their point of origin.

In the materials at hand the tabulæ-seen only in some of the zoøcia-are so scanty and ill-defined that it is not possible to say whether they are perforate or complete. The ratio of axial region to diameter is $0.5: 1$.

Seen in tangential sections, the zoœcia have occasionally a petaloid outline. A number of them are seen to be encircled by a dark ring separated from the zoccial cavity by a narrow light-coloured band. The interzoceial spaces are occupied by a variable number of unequal-sized, sub-angular mesopores, and by numerous conspicuous acanthopores. The latter are mostly of the same size, and often show the central lumen.

Distribution.-The only specimens which can with certainty be referred to D. miliaria are a few metatypes in the Nicholson Collection. They are from Redesdale, Northumberland. Nicholson's statement that the form is common in the Lower Carboniferous rocks of Great Britain generally, is not corroborated by the examination of his collection. In fact, species possessing mesopores are rather rare in this country. Specimens in the main resembling the Redesdale species, but differing in having fewer mesopores, were collected by Mr. J. Rhodes in the bed of the river Black Line, opposite Cumcrook, one mile S. of Clattering Ford, Cumberland [R. 2679].

Observation.-The original of Nicholson's species was not available, but the foregoing description is drawn up from the examination of metatypes in the Nicholson Collection.

Dyscritella nana sp. nov.

Plates XIV, fig. 11 ; XVI, figs. 18-20.

Description.-(a.) External characters. The zoarium consists of small, solid, cylindrical, dichotomous branches averaging less than $1 \mathrm{~mm}$. in diameter. There are some sixty zoœcial apertures along a distance of $1 \mathrm{~cm}$. They are slightly oval and are separated by interspaces equal to their own diameter. The interspaces appear either as pierced by the minute angular apertures of the mesopores, or as solid, the apertures of the mesopores being probably in that case filled by a secondary deposit of sclerenchyma. No acanthopores are to be seen.

(b.) Internal structure. The change of direction from the axial region to the periphery is abrupt, and the thick portion of the walls is short and approximately at 
right angles to the surface. A few centrally perforated tabula occur in the axial portion of the zoœcia, but they are totally absent in the peripheral region-in the zoœcia as well as in the mesopores.

The ratio of axial region to diameter is $0 \cdot 6: 1$. Tangential sections differ widely, according to whether they run through open or through partly closed mesopores. In the first case the mesopores appear as angular apertures separated by narrow partitions, while in the second case they appear as minute sub-circular holes in a mass of tissue. The illustrations in pl. xvi., figs. 19, 20, represent these two aspects of the same zoarium. The few acanthopores observed are very small and inconspicuous.

Jistribution.-A large specimen of limestone collected by Mr. J. Rhodes in the Trout Beck, below Dumblar Rigg, King Water, Cumberland [R. 2965], is entirely made up of colonies of $D$. nana, a rare instance of a rock-forming Trepostomatous Bryozoon. It has not come under notice from any other locality.

Observation.-The small size and gregarious habit of this species distinguish it readily from the other species described here, to none of which it seems to bear any affinities.

The original of pl. xvi., figs. 18-20, is preserved in the Collections of the Geological Survey in London.

\section{Dyscritella multifida sp. nov. \\ Plate XVI, figs. 13-15.}

Description.-In the two specimens that have come to hand the zoarium consists of solid cylindrical dichotomous branches 4 and $5 \mathrm{~mm}$. in diameter respectively. The surface is not shown.

Internal characters. The change of direction towards the periphery begins early and gradually, and the zoccia reach the surface without an abrupt bend. The axial region is extremely narrow, being about one-third of the diameter. In the peripheral region the walls are not appreciably thick: the repeated intercalation of numerous deep-set mesopores gives them a remarkably complex dendritic appearance in longitudinal sectiuns. Tabulæ are entirely wanting in both mesopores and zoœcia. There are some forty zoœcia along a distance of $1 \mathrm{~cm}$. Seen in tangential sections, the zoœcia as well as the mesopores have a sub-angular outline. They are interspersed with numerous very large and conspicuous acanthopores, much darker than the general tissue. 
Distribution.-The original of pl. xvi., figs. 13-15, is from the Lower Limestone of a locality $1 \frac{1}{2}$ miles $\mathrm{N}$. of Croagh, Townland of Cloonoul, Limerick [936c]. The other specimen is also from the Lower Limestone, and was found in a railway-cutting in the Townland of Curraghbeg, Limerick [983c]. Both are preserved in the Collections of the Geological Survey of Ireland.

\section{Discritella ambigua sp. nov.}

Plate XVI, figs. 11, 12.

Description.-(a.) External characters. In the two specimens at hand the zoarium consists of a solid cylindrical dichotomous branch $7 \mathrm{~mm}$. thick. The apertures, of which some forty occur along a distance of $1 \mathrm{~cm}$., are circular and are separated by rather narrow interspaces occupied by sub-angular mesopores. The acanthopores are very small.

(b.) Internal structure. The peripheral portion of the zoœcia is short and at right angles to the surface, with considerably thickened walls, which assume in longitudinal sections a dendritic appearance due to the irregular intercalation of mesopores.

Tabulæ are so scarce that they easily escape detection. Although the slide from which a portion is figured, pl. xvi., fig. 11, is a large one nearly $2 \mathrm{~cm}$. long, it shows altogether no more than three tabula, in three separate zoccia. They appear as complete, but their true nature cannot be inferred from the aspect of such a restricted number.

The ratio of axial region to diameter is $0 \cdot 6: 1$.

Seen in tangential sections the zoœcia are sub-circular, separated by more or less angular mesopores. The acanthopores are small, and of two sizes which are not distributed according to any definite arrangement.

Distribution.-The two specimens on which this description is based were collected by Mr. C. H. Cunnington, at Penwyllt, South Wales, from the topmost portion of the Carboniferous Limestone. Another example from South Wales came from the crags about 130 yards E.S.E. of Moody Nose, 2 miles S. of Warren (north limb of syncline), Pembrokeshire: horizon D2 [specimen E.D. 1879].

This species is so far only known in Scotland by a specimen from the Lower Limestones of Fulwood Burn, W. of Birkenhead, $3 \frac{1}{2}$ miles S.E. of Carluke, Lanarkshire [specimen T. $4640^{\circ}$ ]. 
Observations.-Two of the mesopores shown in the illustration, pl. xvi., fig. 11, appear as if they were closed: this is probably an effect due to the plane of section being not quite median.

Although longitudinal sections bear some resemblance to sections of the preceding species, D. ambiqua is readily distinguished by its narrower axial region and small acanthopores.

Genus Koninckopora gen. nov. ${ }^{1}$

Koninckopora inflata (de Koninck).

Plates XIV, figs. 17, 18 ; XVI, figs. 21-23.

1842. Calamoprora inflata de Koninck. Description des Animaux Fossiles du Terrain Carbonifère de la Belgique, p. 10, pl. A, figs. Sa, 8b.

1855. Stenopora inflata M'Coy. Systematic description of the British Palæozoic Fossils in the Geological Museum of the University of Cambridge, p. 82.

1872. Monticulipora? infata de Koninck. Nouvelles Recherches sur les Animaux Fossiles du Terrain Carbonifère de la Belgique, p. 146, pl. xiv., fig. 4.

Description.-(a.) External characters. The zoarium appears to be always hollow. Iost of its bulk consists of a very thick epizoarium, which determines the ultimate shape of the colony. The shape varies from that of a more or less flattened hollow cylinder to that of thick lobulated masses in which the epizoarium is folded upon itself.

The surface is uniformly smooth : the partitions of the apertures are not raised, and acanthopores appear to be absent. There are neither monticules nor maculæ. The apertures appear as circular or sub-polygonal, presumably according to the amount of weathering or of rubbing undergone by the surface.

(b.) Internal structure. The epizoarium attains several millimetres in thickness, whilst the length of the attacked zoccia seldom exceeds $0.5 \mathrm{~mm}$. A peculiar feature of this species is that whatever the direction of the section, the zocecia always appear to spring at right angles from the epizoarium without being at first prostrate as is the case in the Trepostomata generally.

'The zoœcia average seventy along a distance of $1 \mathrm{~cm}$. The walls are thin, but with one or two moniliform swellings near the middle of their course, and often expanding at their termination. Slides from English and Belgian materials failed to reveal the presence of 
tabulæ. Occasional hazy lines occupying opposite positions in some of the tubes might suggest the former presence of unfossilisable bodies of the nature of tabulæ, but this is a debatable point and the specimens examined must be considered as devoid of tabulæ.

Acanthopores are absent in shallow as well as in deep sections. When the section runs through the thickened portions of the walls the zoœcia appear as circular, with comparatively thick walls. Conversely, a section passing through the thin portions of the walls shows thin-walled polygonal zoœcia. The illustration given in pl. xvi, fig. 23 , showing the first case, was selected in order to prove more clearly the absence of acanthopores.

Distribution.-Figures 21-23 in pl. xvi. are from specimens collected by Dr. A. Vaughan from the "Brachiopod Bed" of Wetton, Derbyshire, which is presumably of D 2 age (Upper Visean). The earlier appearance of this species is attested by a specimen, likewise supplied by Dr. Vaughan, from the C 2 sub-division at Tickenham, near Clevedon. Specimens from Kendal, Westmoreland, apparently referable to Koninckopora inflata, and identified as such by $\mathrm{M}^{\circ} \mathrm{Coy}$, are preserved in the Sedgwick Museum, Cambridge (No. 301 and 302). Two large specimens from Stebden Hill, Cracoe, Yorkshire, were sliced and correctly identified by Nicholson. They are preserved in the Nicholson Collection, Aberdeen University.

Observations. - The absence of a differentiation of the zoœcia into an axial or immature and a peripheral or mature region, as well as the absence of acanthopores, distinguishes Koninckopora inflata from all the other species described in this contribution. Moreover, until transitional species are found, the systematic position of the genus will be difficult to ascertain. That is, it is at present not possible to say how far the first of these distinguishing characters is to be regarded as fundamental, since we may conceive of a prostrate axial region hidden or resorbed during an abnormal development of epizoarial matter. If we assume the zoœcia to be really undifferentiated, this species cannot then properly be allocated to the Trepostomata, while, following the second alternative, it could be placed in that sub-order, but in a somewhat uncertain position, until some evidence were obtained concerning the tabulation of allied species, if any should be discovered.

De Koninck's description was written before thin sections had come into general use; consequently he does not describe the internal characters of his species. His 
description is nevertheless very good, and suffices for the identification of topotypes. The more important part of his diagnosis is as follows :-

"Polypier de forme très-variable, offrant ordinairement l'aspect de grosses branches irrégulièrement bosselées, à extrémités obtuses et arrondies. Quel que soit cependant le diamètre de ces branches, le polvpier proprement dit n'en occupe qu'une faible partie, qui se présente sous la forme d'une couche très-mince, d'une épaisseur égale dans toute son étendue, et n'atteignant généralement pas au delà d'un demi-millimètre.

Les polypiérites sont done extrêmement courts et ne possèdent pas cette dispusition rayonnante qu'ils affectent dans l'espèce précédante "1 [that is, "Monticulipora tumida"].

The last sentence is significant and shows that de Koninck recognized the essential difference between his species and the Trepostomata typified by "Monticulipora tumida," namely, that here the zoarium is not made up of radiating fasciculated tubes.

Specimens from Visé, agreeing in every respect with de Koninck's description, are preserved in the British Museum (Natural History). Most of them [55524, D. 20613 to D. 20617] are decalcified, as is usually the case with Visé materials, but fortunately specimen D. 20612 is well preserved and it was therefore selected for slicing. The internal features of that specimen are an exact reproduction of those shown by the English materials. Externally it appears as a slightly flattened branch $15 \mathrm{~mm}$. by $10 \mathrm{~mm}$. across its two diameters; but it really consists of two layers, suggesting the beginning of a complex zoarium such as that of the Wetton specimen figured, plate xvi., fig. 21.

Although in most cases the re-description of a species should admittedly rest on the examination of the holotype, it is quite possible that in this particular instance the clear internal features shown by the well-preserved topotype could not have been observed in the original, which is obviously decalcified.

\section{Vil.-Remarks on Distribution and Evolution.}

The species described in this memoir do not by any means constitute the whole of the British Lower Carboniferous trepostomatous fauna. The forms referred to in the various comparative remarks, as well as a number of other's macroscopically studied, are represented by single or indifferently preserved specimens, the detailed description of which may be fitly deferred until more suitable materials can also be examined. Yet, as 
it stands, the list of the species recorded here is fairly representative and suggests interesting points touching their distribution in this country; and may permit of comparisons with the corresponding faunas of foreign countries.

The most outstanding feature of the British Carboniferous Trepostomata is the remarkably restricted distribution of the species, vertically and horizontally. Since most of the materials examined here form part of general assemblages of fossils systematically collected by skilled hands, the restricted distribution of the species cannot be solely attributable to the uncertainties necessarily inherent to fossil-collecting, and it seems that various physical causes such as the temperature and degree of purity of the water probably played a leading part in the distribution of these organisms. That the apparently restricted occurrence is real and not due to faulty observation seems to be the more probable when we consider the more conspicuous species, such as Tabulipora howsei (Nich.) : such a striking object could not possibly fail to attract the attention even of a casual observer, so that the absence of that species-in England-South of Northumberland is probably due to adverse physical conditions in that area.

As regards the vertical distribution, it is not easy to estimate the parts played by physical causes and evolution respectively. The vertical range is narrow, and the species do not recur, although conditions favourable to the development of the Trepostomata generally, prevailed from time to time throughout the Lower Carboniferous sequence. As already stated in the first part of this memoir, so little is known of the ontogenetic development of the Trepostomata that we are not yet in possession of satisfactory means for showing the possible existence of genetic relationships between species occurring in successive zones.

The distinguishing characters to which a specific importance is given are so salient that it is difficult to believe that they could be due to a process of gradual evolution. In that respect some light may be obtained by a comparison with the North American fauna. In North America there seems to be no great differences between the Lower and Upper Carboniferous related types, perhaps less than between any two British forms separated by a lapse of time much shorter than that between Lower and Upper Carboniferous. That is, there is no evidence that in North America species originated by sudden mutational changes, and there is no apparent reason why the evolution of the forms should have proceeded differently in this country. The Trepostomata of Lower Carboniferous times cannot be said to be approaching extinction, so that the diversity of types does not seem to be attributable to racial degeneracy. Widespread species such as Stenopora redesdalensis and Tabulipora howsei are very stable, only a few evincing 
instability (e.q. Tabulipora scotica and T. sparsitabulata). Another striking feature of the British fauna is the presence of singular species apparently unconnected with the other members of the group; for instance Koninckopora inflata and Tabulipora debilis.

All these facts, namely the narrow vertical range, the often circumscribed horizontal distribution and the absence of visible links between the greater number of the species, seem to point to the influence of physical causes-not necessarily shown by the nature of the sediment-having favoured from time to time the immigration of the various types from some outside area. But the very complexity of our fauna precludes the possibility of offering suggestions as to the probable situation of its centre of dispersion. Comparisons with the Lower Carboniferous trepostomatous faunas of continental Europe cannot yet be attempted, in some cases owing to the fact that Trepostomata are not represented, in others on account of incomplete knowledge. On the other hand the North American fauna is very well known, and is the only one with which comparisons can be made. The relationship of the British and North American faunas lies in the presence of Leioclema, Batostomella and Dyscritella, and of the species of Tabulipora with centrally perforated tabulæ [Tabulipora, Section A = Stenopora Auctt.], all of which genera are represented in these two countries by more or less closely comparable species. But the resemblance ceases here. Stenopora (as restricted), the numerous species falling under Section B of Tabulipora and the "Monticulipora inflata," have no equivalents in North America.

From the fact that besides the species classed here as Stenopora, the genus Stenopora Lonsdale [non Auctt.] exists only in the Upper Palæzoic deposits of Australia and India (? Russia), one of two conclusions can be drawn: the British forms are either true Stenoporce, in which case the genus originated in the Atlantic area and then migrated eastwards, or they are but homœomorphs of the Australian species.

The purely theoretical points discussed above do not in the least detract from the real value which it is hoped the Trepostomata will be shown to possess as indices in correlating beds over considerable areas, when inore becomes known of the occurrence of many of the species which at present are recorded from single localities only. Although many of the species, owing to their restricted occurrence-so far as the materials examined go-cannot yet be proved to be useful, it will be admitted that the numerous locality-records of others show them to be trustworthy indices in certain areas. For instance, Stenopora redesdalensis and Tabulipora howsei are common in Northumberland, Cumberland and the South of Scotland in beds of D 1 age approximately. T. scotica and T. youngi, common in Central Scotland, have not been observed from beds older than the top of the 
Visean ; that is, their age is either D 3 or top of D 2. T. sparsitabulata, which is found in the South-West Province as well as in the North British area, is another species the age of which is approximately D 1.

The following table shows the approximate stratigraphical position of the species named in this contribution. It will be seen at a glance that the majority belong to the top half of the Visean, few being Tournaisian or Lower Visean. Although the materials examined may be taken in a broad way to be representative of the actual relative abundance of the Trepostomata in the main sub-divisions of the Lower Carboniferous rocks, it is to be hoped that diligent search may yet help to fill the gaps.

Table showing the Distribution of the British Lower Carboniferous Trepostomata.

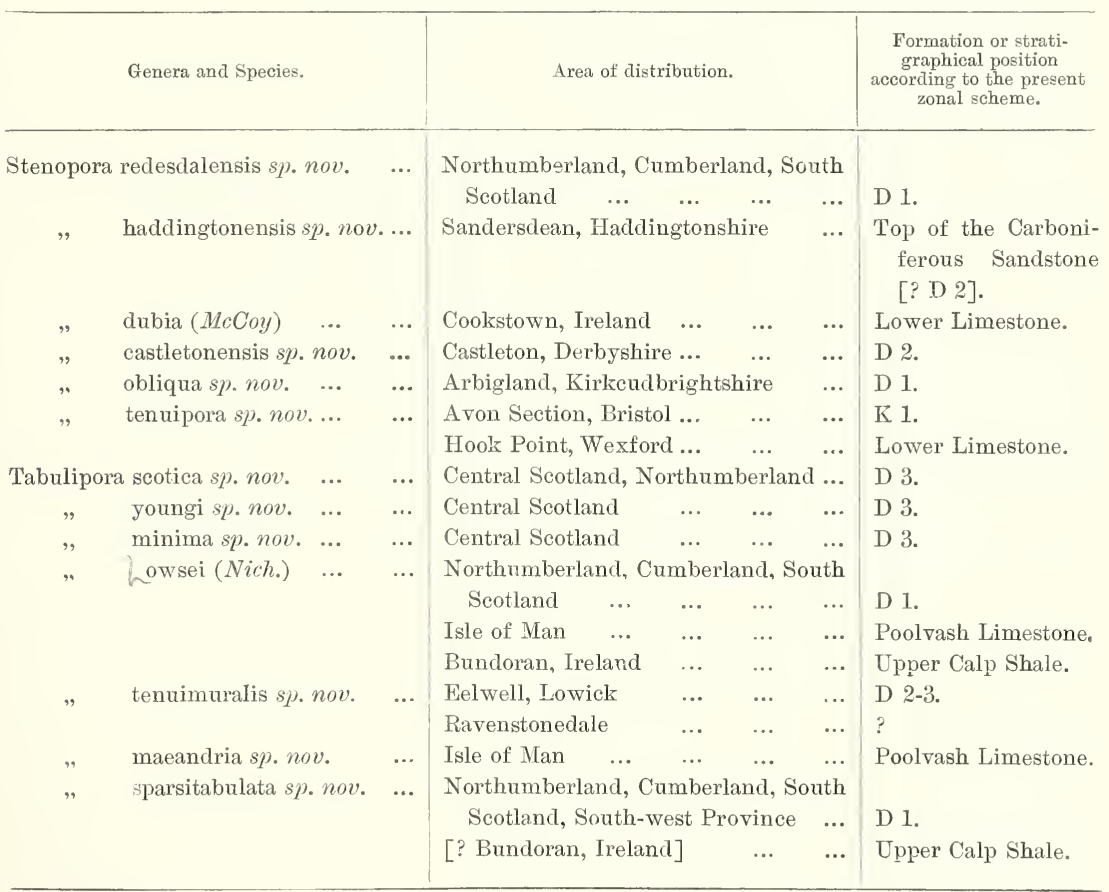




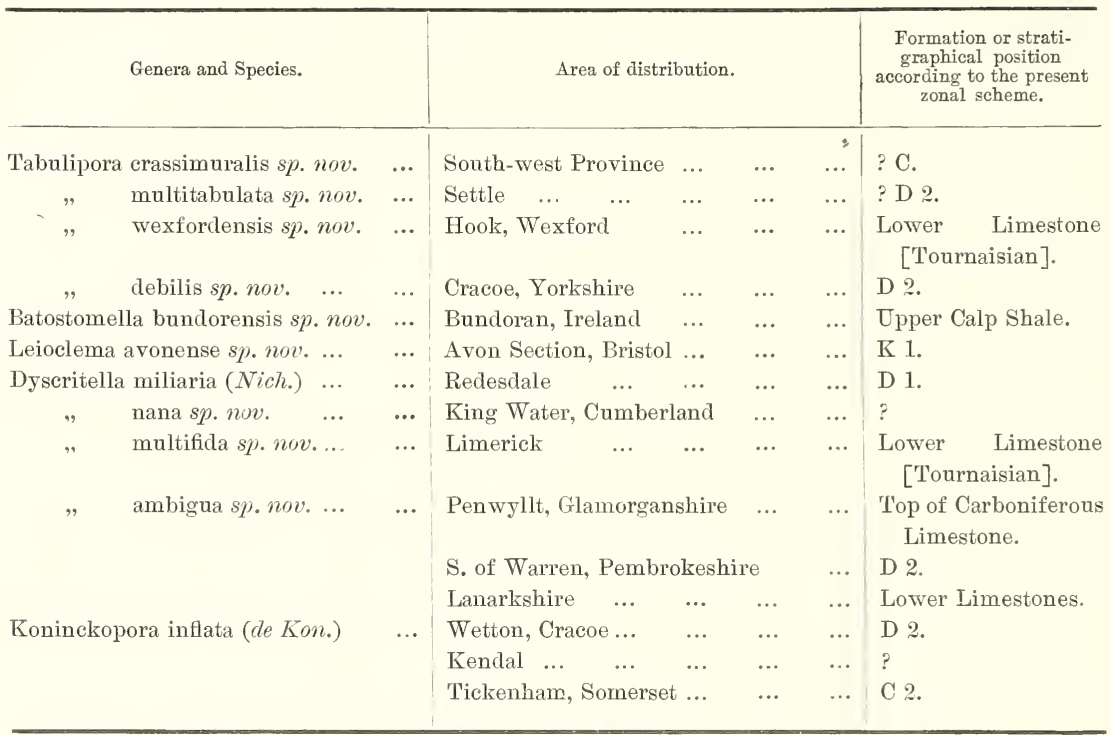

To Dr. F. L. Kitchin and Mr. W. D. Lang grateful thanks are due for valuable advice and support during the preparation of this paper; and to Miss G. Elles, Dr. R. S. Scharff, Dr. A. W. Gibb and Mr. P. Macnair for courteous help during the examination of materials in their charge. Further, this memoir could not have been prepared without the examination of materials kindly lent by Dr. Wheelton Hind, Dr. A. Vaughan, Dr. T. F. Sibly, Mr. W. B. Wright, Mr. J. Smith, Mr. R. Dunlop and Mr. J. Wright. 


\section{VIII.-Bibliography.}

1. Bassler, R. S. The Bryozoan Fatina of the Rochester Shale, United States Geol. Surv. Bulletin, No. 292, 1908.

1a. Bounne, G. C. Structure and affinities of Heliopora coerulaea Pallas, Phil. Trans. Roy. Soc., vol. 186, B, Part I, 1895, pp. 455-483.

2. Cumings, E. R. A Revision of the Bryozoan Genera Dekayia, Dekayiella and Heterotrypa of the Cincinnati Group, The American Geologist, vol. xxix., no. 4, 1902, p. 197.

3. " " $" \quad$ Development of some Palæozoic Bryozoa, American Journal of

Science, Series 4, vol. xvii., 1904, p. 49.

4. " " $\quad$ Development of Fenestella, Ibid., vol. xx., 1905, p. 169.

5. Drвowski, W. Über die Gattung Stenopora Lonsdale, mit besonderer Berücksichtigung der Stenopora columnaris Schloth. sp., Trerhandl. der Russisch-Mineral. Gesellsch. zu st. Petershurg, Ser. 2, vol. xii., 1877, pp. 65-78.

5a. " " $"$ Die Chaetetiden der Ostbaltischen Silur-Formation. Ibid., xiv, 1879, pp. 1-134.

6. Etheridge, R. (Jun.). Observations on Chaetetes tumidus, Phill., Ann. Mag. Nat. Hist., Fourth Series, vol. xiii., 1874, p. 194, pl. xi, figs. $1-3$.

7.,$\quad$ A Monograph of the Carboniferous and Permo-Carboniferous Invertebrata of New South Wales, Part I, Coelenterata, Memoirs of the Geological Survey of New South Wales, Palæontology, No. 5, 1891.

See also NichoLson.

8. Fleming, J. A History of British Animals. Edinburgh, 1808.

9. Geological Survey of Scotland, Memoirs of. Explanation of Sheet 5, Kirkcudbrightshire, 1896.

10. Gintr, G. H. The Guadalupian Fauna, United States Geol. Surv., Prof. Paper No. 58, 1908.

11. " " Descriptions of New Species of Upper Palæozoic Fossils from China. Proc. of the L'nited States Nat. Mus., vol. xxxiii., 1908 , p. 42. 
11a. Ginty, G. H. New Genera and Species of Carboniferous Fossils from the Fayette= ville Shale of Arkansas, Annals of the New York Academy of Sciences, vol. xx., no. 3, part ii., 1910, pp. 189-238.

12. Gregory, J. W. Catalogue of the Fossil Bryozoa in the Department of Geology, British Museum (Natural History). The Jurassic Bryozoa, 1896.

13. " " $\quad$ Ibid., The Cretaceous Bryozoa, vol. ii, 1909.

14. Hall, J. Geological Survey of the State of New York. Palceontology: vol. vi., Corals and Bryozoa, 1887.

15. Koninck, L. G. DE. Description des Animaux Eossiles qui se trouvent dans le Terrain Carbonifère de la Belgique, 1842-4.

16. ",$\quad$ Nouvelles Recherches sur les Animaux Fossiles du Terrain Carbonifère de la Belgique, 18 ז2.

17. Lang, W. D. The Reptant Eleid Polyzoa, (đ̃eol. Mag., Dec. V., rol. iii., 1906, pp. 60-68.

17a. Lindström, G. Nagra Anteckningar om Anthozoa Tabulata, Öfversigt af Kongl. Vetensk. Akad. Förhandl. for 1873, No. 4, 1874, pp. 3-20.

18. $" \quad, \quad$ On the Affinities of the Anthozoa 'Tabulata, Ann. Mag. Nat. Hist., Series 4, vol. xviii., 1876, pp. 1-17.

19. Lonsdale, W. In P. E. Strzelecki's "Physical Description of New South Wales," 1845 , pp. 262-269.

20. " " Description of some characteristic Palæozoic Corals of Russia, in Murchison's "Russia and the Ural Mountains," vol. i., Appendix A, 1845, pp. 591-634, pl. A.

21. M'Cor, F. A Synopsis of the Characters of the Carboniferous Limestone Fossils of Ireland. Dublin, 1844.

22. " "Systematic description of the British Palæozoic Fossils in the Geological Museum of the University of Cambridge. 1855.

23. " " On some new Genera and Species of Palæozoic Corals and Foraminifera, Ann. Mag. Nat. Hist., Series 2, vol. iii., 1849, pp. 1-20, 119-136.

24. Milne-Edwards, H., and Haime, J. A Monograph of the British Fossil Corals (Palceontographical Society). 1850-4. 
25. Nicholson, H. A. On the Structure and Affinities of the "Tabulate Corals" of the Palæozoic Period. Edinburgh and London, 187!). 26. $\quad, \quad$ On the Structure and Affinities of the Genus Montieulipora and its Sub-Genera. Edinburgh and London, 1881.

27. " " Contributions to Micro-Palæontology-On Stenopore IIorsii. Nich., with Notes on Monticulipora? tumila, Phill., and Remarks on Tabulipora Urii, Ioung, Ann. Mag. Nat. Hist., Series 5, vol. xii., 1883, pp. 285-297. 28. , , . and Etheridge, R. (Jux.). Description of Palæozoic Corals from Northern Queensland, with Observations on the Genus Stenopora, Ann. Maq. Nat. Hist., Series 5. vol. iv., 1879, pp. 216-226, 265-285.

29. " ". and Etheridge, R. (Jun.). On the Tasmanian and Alistralian species of the Genus Stenopora, Lonsdale, Ann. Mag. Nat. Hist., Series 5, vol. xrii., 1\$s6, pp. $173-187$.

30. " " and Lrdekrer, R. A Manual of Palaontology for the use of Students. Edinburgh and London, 1889. The Monticuliporids, pp. 346-360.

31. Nickues, J. M., anả Bassler, R. S. A Synopsis of American Fossil Bryozoa, United States Geol. Surv. Bulletin No. 173, 1900.

32. Phillips, J. Illustrations of the Geology of Yorkshire, Part II., London, 1836.

33. Portuck, J. E. 'Report on the Geology of the County of Londonderry and of parts of Tyrone and Fermanagh. Dublin, 1843.

34. Rogers, A. F. New Bryozoans from the Coal Measures of Kansas and Missouri. Kansas L'nicersity Quarterly, Ser. A, vol. ix., No. $1,1900$.

35. Romaxowsis. [A Memoir on Stenopora, in Russian.] Verhandl. der Russisch. Kaizerl. Mineral. Gesell. zu St. Petersburg, vol. xxviii.. 1891, pp. 169-192, pl. vi.

35a. Reminger. C. Observations on Chaetetes and some related genera, in regard to their systematic position, with an appended description of some new species, Proc. Acad. Nat. Sci.. Phitadelphia, 1866, pp. 113-123. 
35b. Sardeson, W. Über die Beziehungen der fossilen Tabulaten zu den Alcyonarien. Neues Jahrbuch für Nineralogie, Geologie und Palckontologie, Beilage-Band x., pp. 249-362, Stuttgart, $1895-6$.

36. Simpson, G. B. A Handbook of the Genera of the North American Falæozoic Bryozoa, Fourteenth Annual Report of the State Geologist for the year 1904. New York, 1904.

37. Sмrтн, S. The Faunal Succession of the Upper Bernician, Trans. Nat. Hist. Soc. of Northumberland, Durham and Nevcastleupon-Tyne, New Series, vol. iii., Part 3, 1909, pp. $591-645$.

38. Stuckenberg, A. Anthozoen und Bryozoen des Oberen mittelrussischen Kohlenkalks, Mém. du Comité Géol. de la Russie, vol. v., No. 4, 1888.

39.,$\quad$ Korallen und Bryozoen der Steinkohlenablagerungen des Ural und des Timan, ibid., vol. x., No. 3, 1895.

40. Trautschold, H. Die Kalkbriiche von Mjatschkowa: Eine Monographie des oberen Bergkalks, Nouv. Mém. Soc. Imp. Nat. Mosc., tome xiii., 1876 , pp. $88-97$.

41. Ulrich, E. O. American Palæozoic Bryozoa, The Journal of the Cincinnati Society of Nat. Hist., vol. v., No. 3, 1882, pp. 121-175; No. 4, pp. 232-257.

42. " " Palæozoic Bryozoa, Palcontology of Illinois. Geology of Illinois, vol. viii., part 2 , section 6,1890 , pp. $283-6 \$ 8$.

43. ", " Bryozoa. The Geology of Minnesota, vol. iii., part 1 of the Final Report, Palceontology, 1895.

44. " , Bryozoa. In Eastman's Translation of Zittel's Text-Book of Palæontology, vol. i., pp. 257-291, 1896.

45. " " and Bassler, R. S. A Revision of the Palæozoic Bryozoa, Part II. On Genera and Species of Trepostomata, Smith. Miscell. Coll. (Quart. Issue), xlvii. [for 1904], 1905, pp. 15-5う.

46. Vaughan, A. Faunal Succession in the Lower Carboniferous (Avonian) of the British Isles, Report 84 of the British Assoc., Section C, IVinnipeg Neeting, $1909 ; 1910$. 


$$
\text { G. W. Lee-Trepostomata. }
$$

47. Une, D. The History of Rutherglen and East Kilbride. Glasgow, 1793.

48. Vine, G. R. Further Notes on New Species, and other Yorkshire Carboniferous Fossils described by Prof. John Phillips, Proc. Yorks. Geol. and Polytech. Soc., New Series, vól. viii., part 3, 1884, pp. 37亍-393.

49. Whager, II., and Wextzer, J. Coelenterata. Salt Range Fossils, vol. i., Productus Limestone Fossils, 1887. Palceontologia Indica, Ser. xiii.

49a. Weissermez, W. Sind die Tabulaten die Vorlïufer der Alcyonarien, Zeitschrift der deutschen geologischen Gesellsch̆aft, Bd. 50, 1898, pp. 54-78.

50. Young, J. On Ure's "Millepore," Tabulipora (Cellepora) Urii, Flem., Ann. May. Nat. Hist., Series 5, vol. xii., 1883, pp. 154-158.

50a. " " Notes on Ure's "Millepore," Tabulipora Urii, J. Young (Cellepora Crii, Flem.). Transactions of the G'eoloyical Society of Glasgour, vol. vii., 1885, pp. 264-272.

ว1. Zitrel, K. A. vox. Handbuch der Palæontologie, 1876-18@0.

5la. , " , Grundziige der Palæontologie (Palæozoologie). Neubearbeitet von Dr. Ferdinand Broili. Miinchen and Berlin, 1910, pp. 249-259. 


\section{INDEX OF GENERA AND SPECIES.}

Synonyms and invalid names are printed in italic type.

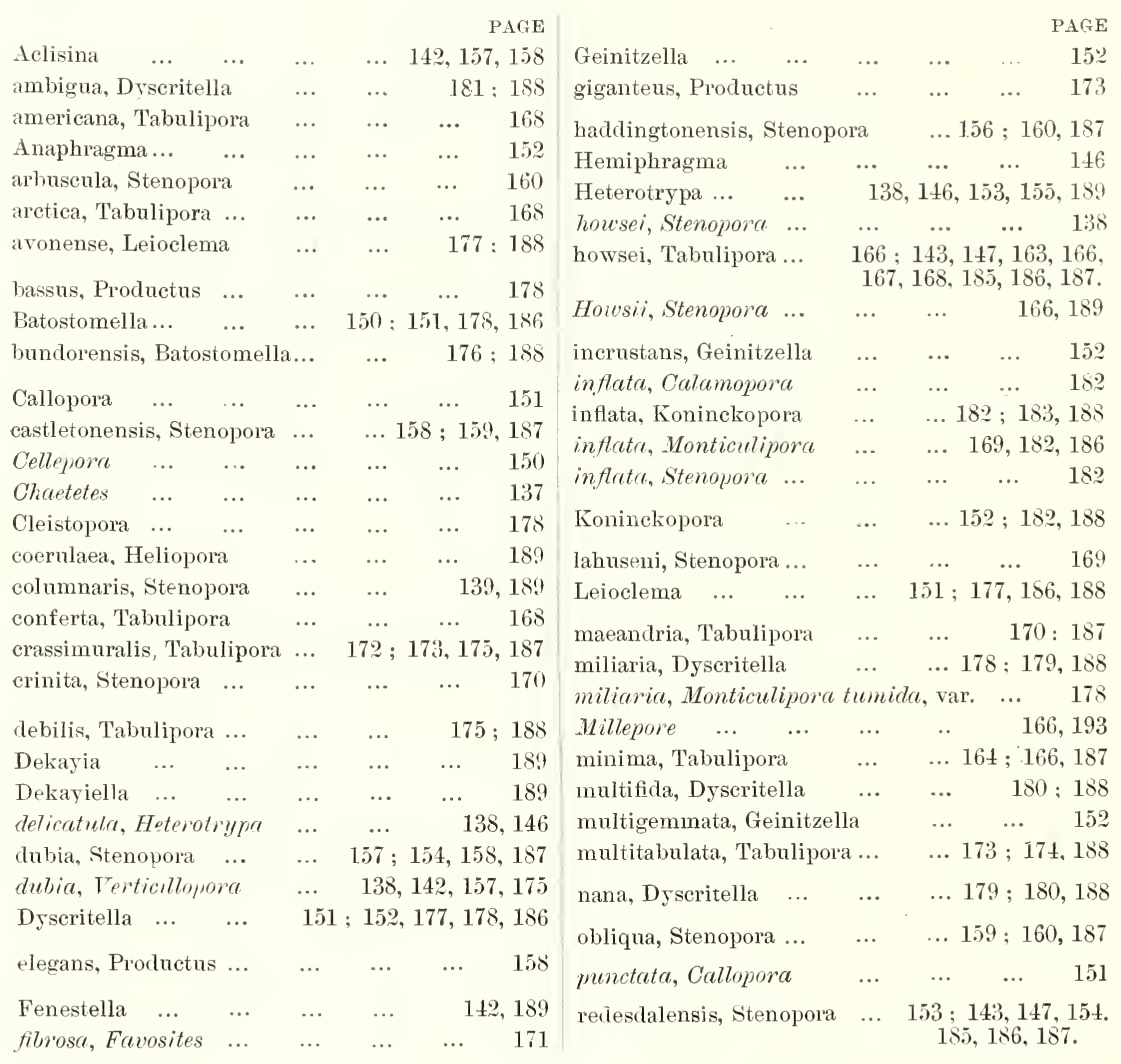


PAGE

scotica, Tabulipora $\ldots \quad 162 ; 143,1 \pm 7,150,163$, $166,168,186,187$.

$\begin{array}{llllllll}\text { Seminula } & \ldots & \ldots & \ldots & \ldots & \ldots & 154\end{array}$

sparsitabulata, Tabulipora ... 171; 17\%, 173, 186, 187.

$\begin{array}{llllll}\text { spinosa, Stigmatella } & \ldots & \ldots & \ldots & 1 \pm 6\end{array}$ spinulosa, Batostomella $\quad \ldots \quad \ldots \quad \ldots \quad \ldots \quad 177$

Stenopora $\quad \ldots \quad 1 \pm 7 ; 139,1 \pm 6,1 \pm 8,150,157$, $186,187,189,191$.

$\begin{array}{lllllll}\text { Stenopora sp. } & \ldots & \ldots & \ldots & \ldots & 155\end{array}$

$\begin{array}{llllllll}\text { Stigmatella } & \ldots & \ldots & \ldots & \ldots & \ldots & 146\end{array}$

subfrondosa, Dekaria $\quad$... ... ...

Tabulipora $\quad \ldots \quad \ldots \quad 149 ; 146,150, \mathbf{l} 62,168$, $186,188,191,193$.

Tabulipora sp. $\quad \ldots \quad \ldots \quad 163,165,175,176$ tasmaniensis, Stenopora $\quad \ldots \quad$... $\quad$.. $\quad 149$

PAGE

tenuimuralis, Tabulipord ... tenuipora, Stenopor:a

tumida, Calemopora

tumida, Favosiles ..

tumida, Monticulipora

tumidus, Chaetetes ..

wrei, Cellepora

urei, Tabulipora $\quad . .$.

Urii, Tabulipora ... ...

Verticillopora

wexfordensis, Tabulipora ...

youngi, Tabulipora ...
... 169; 170,187

$161 ; 159,160,187$

.. $\quad \ldots \quad 138,155$

$\begin{array}{llll}. & \ldots & \ldots & 168\end{array}$

$138,153,155,166$ $184,191$.

... 160,189

... 138,150

... $150,163,165$

... $166,191,193$

$138,142,157,175$

$\ldots 17 \pm ; 160,188$

$16 \pm ; 166,186,187$ 


\section{EXPLANATION OF PLATE XIV.}

The specimens figured in this and in the following two plates are in the Survey collections, except when otherwise stated.

FIG. 1A. Diagrammatic representation of the transverse aspect of a zoceinm showing a centrally perforated tabula.

$\mathrm{aa}$ and $\mathrm{bb}$. Intersections of two longitudinal sections. Yage 141 .

FIG. 1B. Aspect of A when cut by section aa.

FIG. 1C. , , , , , , bb.

FIG. 2A. Diagrammatic representation of the transverse aspect of a zoceium showing a laterally perforated tabula.

$\mathrm{aa}, \mathrm{bb}, \mathrm{cc}$, and dd are the intersections of various longitudinal sections. Page $1 \pm 1$.

FIG. 2B. Aspect of A when cut by section aa.

Fig. 2C. , , , , , , , bl.

FiG. 2D. " " $\quad, \quad, \quad, \quad, \quad, \quad$ ec.

FIG. 2E. ", ", " ,,$\quad$ dd.

FIG. 3. Diagram illustrating the mode of growth of a branching trepostomatous Bryozoon according to the hypothesis of resorbtion. In black: the colony as seen in longitudinal section. Stippling: terminal portion of the same, during an earlier period of its existence, and supposed to have been resorbed. Broken lines: terminal portion of the same, as it might have been had it continued to grow. Page 144.

FIGs. 4A-4D. Tabulipora scotica sp. nov., $\times 1 \% 2$.

Diagrammatic aspect of longitudinal sections showing extremes in size, and the relative proportions of the axial and peripheral regions. Page 162.

FIGS. 5A-5D. Stenopora redesdalensis sp. nov., $\times 1 \cdot 2$.

Diagrammatic aspect of longitudinal sections showing extremes in size and the relative proportions of the axial and peripheral regions. Page 153.

Fig. 6. Tabulipora sp.

Diagrammatic aspect of longitudinal section, $\times 1 \% 2$. From Bowsden Quarry, Lowick, Northumberland. [Slide G. W. L. 203.] Page 165.

Fig. 7. Tabulipora sparsitabulata sp. nov.

Diagrammatic aspect of longitudinal section, $\times 1 \%$. Page 171 .

FIG. 8. Tabulipora crassimuralis sp. nov.

Diagrammatic aspect of longitudinal section, $\times 1 \%$. Page $17 \%$.

Figs. 9A-9C. Tabulipora howsei (Nich.).

Diagrammatic aspect of transverse sections, $\times 1 \cdot 3$, showing extremes in size and the relative proportions of the axial and peripheral regions. Page 166.

FIG. 10. Stenopora tenuipora sp. nov.

Diagrammatic aspect of longitudinal section, $\times 12$. Page 161 . 
MEMOIRS OF THE GEOLOGICAL SURVEY OF GREAT BRITAIN.

Palaeontology. Vol. I, 1912.

Plate XIV.

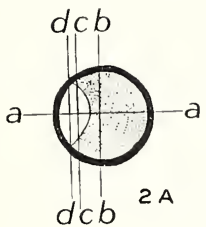

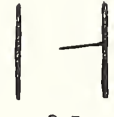

$2 B$

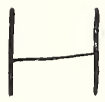

$2 \mathrm{C}$

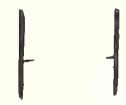

20

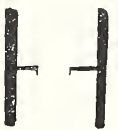

IB
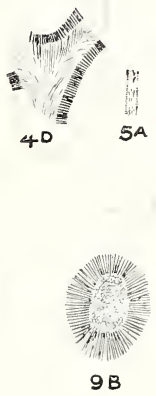

$9 \mathrm{~A}$

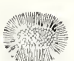

辣

8

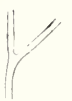

11

12

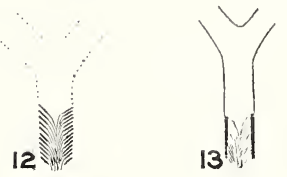

11111111191

17

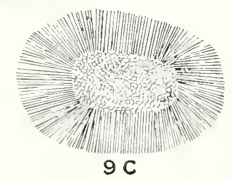

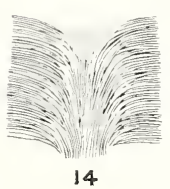

14

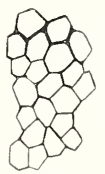

18

T. A. Brock, del. 

FIG. 11. Dyscritella nana sp. nov.

Ontline of zoarium, $\times 1 \cdot 3$. Page 179.

FIG. 12. Stenopora olliqua sp. nov.

Diagrammatic aspect of longitudinal section, $\times 1 \cdot 2$. Page 159.

Frg. 13. Tabulipora wexfordensis sp. nov.

Diagrammatic aspect of longitudinal section, $\times 1 \cdot 2$. Page 174 .

FIG. 14. Leioclema avonense sp. nov.

Diagrammatic aspect of longitudinal section, $\times 1 \cdot 3$. Page 177.

FIG. 15. Leioclema avonense sp. nov.

Transverse section $\times 8$. From the lower portion of the Avon Section, Zone K1. [Slide G. W. L. 213.] Page 177.

FIG. 16. Leioclema avonense sp. nov.

Tangential section $\times 8$. The same specimen as the preceding. [Slide G. W. L. 211.] Page 177.

Fig. 17. Koninckopora inflata (de Koninck).

Portion of peripheral region of longitudinal section $\times 20$. From Visé, Belgium. Originaĩ in British Museum (Nat. Hist.). [ Slide 20612.$]$ Page 182.

FIG. 18. Koninckopora inflata (de Koninck).

Small portion of surface slightly ground down, $\times 20$. The same specimen as the preceding. Page 182.

(NotE.-Owing to difficulties of reproduction, the lines in the axial region are relatively too coarse in figures $4 \mathrm{~A}-4 \mathrm{D}, 5 \mathrm{~A}-5 \mathrm{D}, 6,7,8,10,12$ and 13.) 


\section{EXPLANATİON OF PLATE XV.}

FIG. 1. Stenopora redesdalensis sp. nov.

Longitudinal section $\times 5$. From the Redesdale Ironstone Shale. Original collected

by Mr. Stanley Smith. [Slide G. W. L. 172.] Page 153.

FIG. 2. Stenopora redesdalensis sp. nov.

Tangential section $\times 10$. The same specimen and slide as the preceding. Page 153.

FIG. 3. Stenopora haddingtonensis sp. nov.

Tangential section $\times 15$. From the Calciferous Sandstone Series of Sandersdean.

Haddingtonshire. [Specimen M. 308, slide G. W. L. 198.] Page 156.

FIG. 4. Stenopora haddingtonensis sp. nov.

Longitudinal section $\times 10$. The same specimen and slide as the preceding. Page 156 .

Fig. 5. Stenopora obliqua sp. nov.

Longitudinal section $\times 10$. From the Calciferous Sandstone Series of Arbigland, Kirkcudbrightshire. [Specimen M. 3317", slide G. W. L. 167.] Page 159.

FIG. 6. Stenopora tenuipora sp. nov.

Longitudinal section $\times 10$. From the lower portion of the Aron Section, Zone K 1 .

Original in the Collection of Dr. A. Vaughan. [Slide G. W. L. 163.] Page 161.

FIG. 7. Stenopora tenuipora sp. nov.

Tangential section $\times 20$. The same specimen as the preceding. [Slide G. W. L. 162.] Page 161.

FIG. 8. Stenopora dubia ( $\left.\mathrm{I}^{\circ} \mathrm{Coy}\right)$.

Transverse section $\times 10$, from the holotype. From the Lower Limestone of Cookstown,

Ireland. Original in the Griffith Collection, Dublin. [Slide G. W. L. 183.] Page 157.

FIG. 9. Stenopora castletonensis sp. nov.

Longitudinal section $\times 10$. From the Carboniferous Limestone of Treak Cliff, Castleton, Derbyshire. Original collected by Dr. T. F. Sibly. [Slide G. W. L. 200.] Page 158.

FIG. 10. Stenopora castletonensis sp. nov.

Tangential section $\times 20$. The same specimen as the preceding. [Slide G. W. L. 199.] Page 158.

FIG. 11. Tabulipora sp.

Transverse section $\times 5$. From the Lower Limestones of Trearne, Beith, Ayrshire.

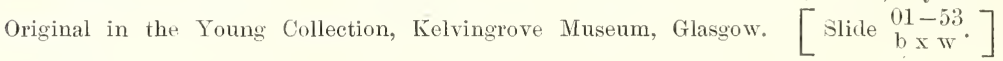
Page 165 .

FIG. 12. Tabulipora scotica sp. nov.

Transverse section $\times 10$. From the white limestone underlying the Hurlet Limestone at Corrie-Burn, Stirlingshire. [Slide (․ W. L. 192.] Page 162.

FIG. 13. Tabulipora scotica sp. nov.

Transverse section X 5. From the Lower Limestones of Hillhead Quarry, Beith, Ayrshire. Original in the Young Collection, Kelvingrove Museum, Glasgow. $\left[\right.$ Slide $\left.\begin{array}{c}01-53 \\ \mathrm{~b} \times \mathrm{s}\end{array}\right]$ Page 162.

FIGs. 14 and 15. The thin incrusting stage of Tabulipora.

Longitudinal section $\times 10$, two aspects of the same section. From the Lower Limestones of Carlops, Midlothian. [Slide G. W. L. 190.] Page 142. 
MEMOIRS OF THE GEOLOGICAL SURVEY OF GREAT BRITAIN.

Palaeontology. Vol.I,1912.
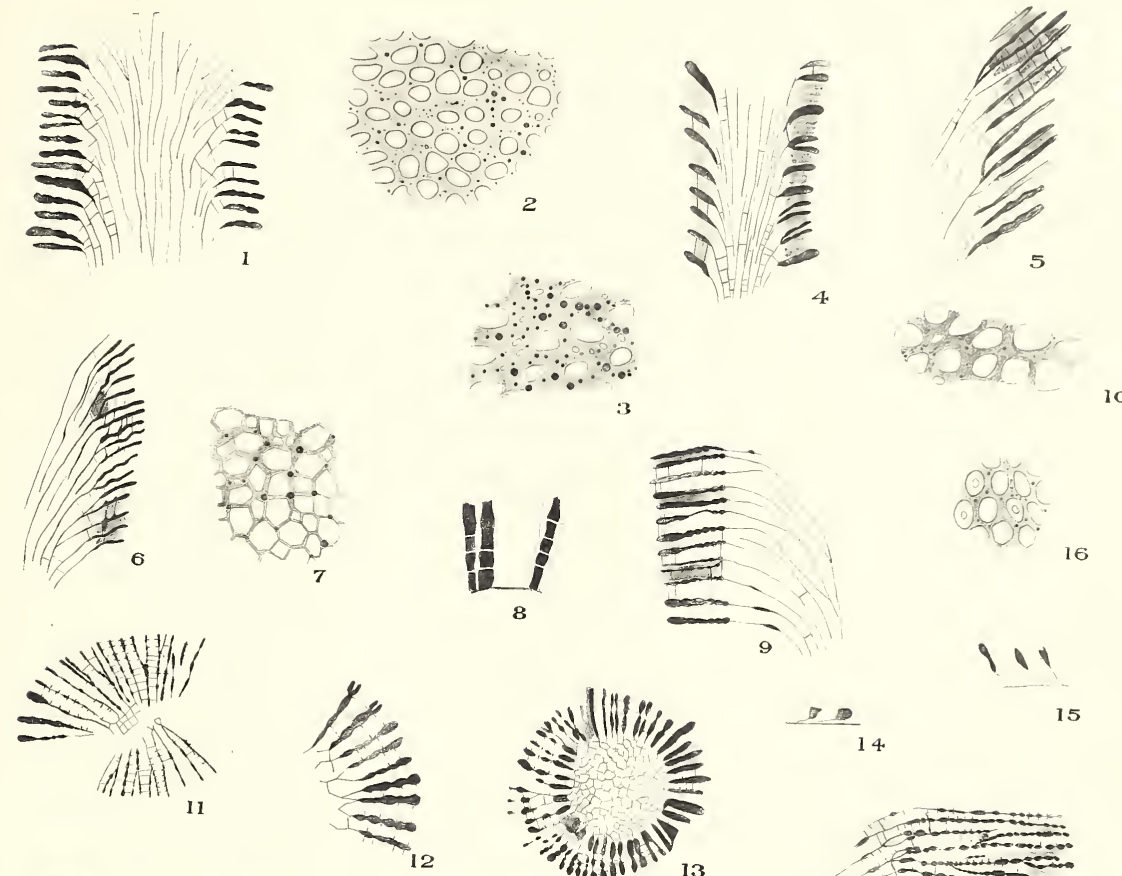

III
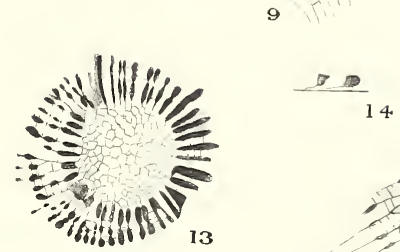

15
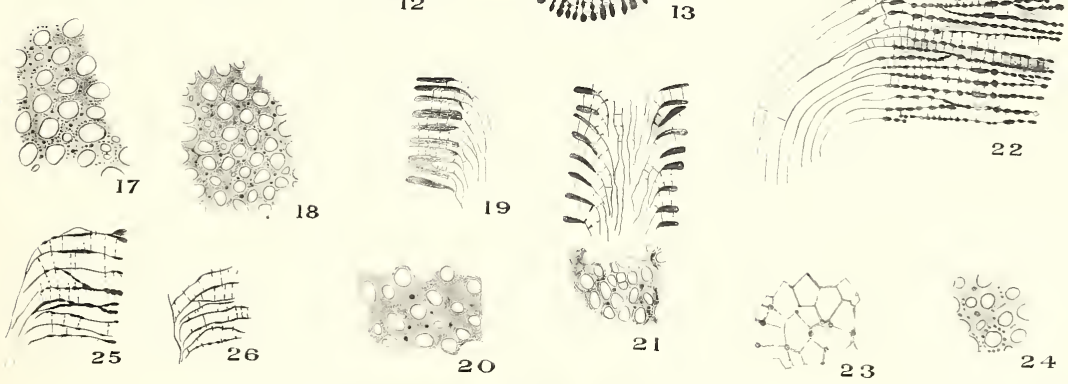

18
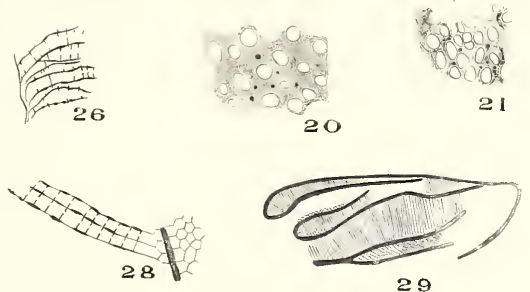

29
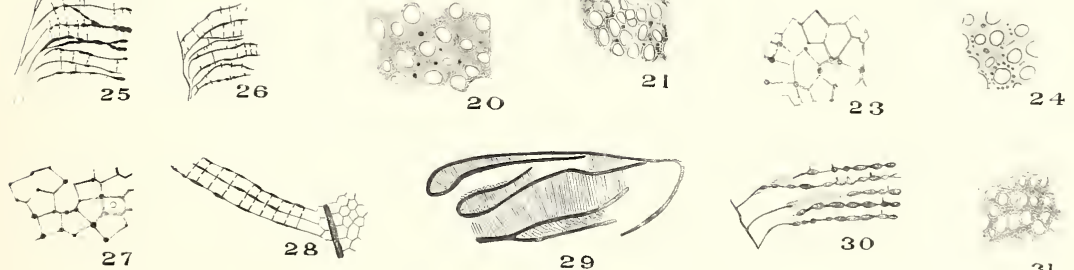
FIG. 16. The thin incrusting stage of Tabulipora.

Tangential section $\times 10$. From the Lower Limestones of Limekilnburn, near EastKilbride, Lanarkshire. [Slide G. W. L. 191.] Page 142.

FIG. 17. Tabulipora scotica sp. nov.

Tangential section $\times 10$. From the Lower Limestones of East-Kilbride, Lanarkshire.

Original in the Young Collection. $\left[\right.$ Slide $\left.\frac{01-53}{\mathrm{~b} \times \mathrm{x}} \cdot\right]$ Page 162.

FIG. 18. Tabulipora scotica sp. nov.

Tangential section $\times 10$. Same specimen and slide as in Fig 12. Page 162.

FIG. 19. Tabulipora youngi sp. nov.

Longitudinal section $\times 5$. From the Lower Limestones of Hillhead Quarry, Beith, Ayrshire. Original in the Young Collection. $\left[\right.$ Slide $\left.\begin{array}{c}01-53 \\ \mathrm{~b} \times \mathrm{r}\end{array}\right]$ Page 164.

FIG. 20. Tabulipora youngi sp. nov.

Tangential section $\times 10$. The same specimen and slide as the preceding. Page 164 .

FIG. 21. Tabulipora minima sp. nov.

Section $\times 10$, eutting the same specimen longitudinally and tangentially. From the Lower Limestones of Howood Quarry, Renfrewshire. Original in the Young Collection. $\left[\right.$ Slide $\left.\begin{array}{c}01-53 \\ \text { b y c }\end{array}\right]$ Page 164

FIG. 22. Tabulipora howsei (Nich.).

Longitudinal section $\times 5$. From the Calciferous Sandstone Series, on the left bank of the River Esk a quarter of a mile N.W. of Gilnockie Tower, Dumfriesshire. [Specimen M. $648^{\text {f }}$, Slide G. W. L. 197.] Page 166.

FIGS. 23 and 24. Tabulipora howsei (Nich.).

Two aspects of the same tangential section $\times 10$. The same specimen as the preceding. [Slide G. W. L. 196.] Page 166.

FIG. 25. Tabulipora tenuimuralis sp. nov.

Longitudinal section $\times 10$. From the Carboniferous Limestone of Ravenstonedale, Westmoreland. Original in the Nicholson Collection. [Slide G. W. L. 195.] Page 169.

FIG. 26. Tabulipora tenuimuralis sp. nov.

Longitudinal section $\times 10$. From the Eelwell Limestone at Eelwell Quarry, near Lowick, Northumberland. [Specimen 25571, Slide G. W. L. 193.] Page 169.

FIG. 27. Tabulipora tenuimuralis sp. nov.

'l'angential section $\times 10$. The same specimen as in Fig. 25. [Slide G. W. L. 194.] Page 169 .

FIG. 28. Tabulipora maeandria sp. nov.

Composite drawing $\times 5$, from a slide and the polished surface. From the white limestone of Poolvash, Isle of Man. Original in the Collection of Mr. J. Smith. Page 170.

FIG. 29. Diagrammatic aspect of a section, natural size, across the zoarium from which the preceding figure is drawn. The thick black line represents the epizoarium.

FIG 30. Tabulipora aff. sparsitabulata sp. nov.

Longitudinal section $\times 10$. From the Lower Carboniferous of Tyrone. Original in the Collections of the Geological Survey of Ireland. [Slide G. W. L. 168.] Page 172.

FIG. 31. Tabulipora sparsitalulata sp. nov.

Tangential section $\nsucc$ 10. From Wood Park, near' Wark, Northumberland. [Specimen 25578, Slide G. W. L. 178.] Page 171. 


\section{EXPLANATION OF PLATE XVI.}

FIG. 1. Tobulipora sparsitabulata sp. nov.

Longitudinal section $\times 10$. From Wood Park, near Wark, Nortbumberland. [Specimen. 25.578, slide G. W. L. 178.] Page 171.

FIG. 2. Tabulipora aff. sparsitabulata sp. nov.

Tangential section $\times 15$. The same specimen as in Fig. 30, Plate $x v$. [Slide

G. W. L. 187.] Page 172.

FIG. 3. Tabulipora multitabulata sp. nov.

Longitudinal section $\times 10$. From the Carboniferous Limestone near stockdale Farmhouse, Settle district. [Specimen Rh. 2247, slide G. W. L. 174.] Page 173.

FIG. 4. Tabulipora multitabulata sp. nov.

Tangential section $\times 20$. The same specimen and slide as the preceding.

F'IG. 5. Tabulipora crassimuratis sp. nov.

Longitudinal section $\times 10$. From a bed belonging probably to the $\mathrm{C}$ zone, Stackpole.

[Specimen E. D. 998, slide G. W. L. 177.] Page 17\%.

FIG. 6. Tabulipora crassimuralis sp. nov.

Tangential section $\times 10$. The same specimen and slide as the preceding.

FIG. 7. Tabulipora wexfordensis sp. nov.

Longitudinal section $\times 10$. From the Lower Limestone of Hook, Wexford, Ireland.

The original in the Collections of the Geological Survey of Ireland. [Slide G. W. L. 182.]

Page 174.

FIG. 8. Tabulipora debilis sp. nov.

Transverse section $\times 10$. From the Carboniferous Limestone of Stebden Hill, Cracoe, near Skipton, Yorkshire. The original in the Nicholson Collection. [Slide G. W. L. 189.] Page 175.

FIG. 9. Dyscritella miliaria (Nicholson).

Tangential section $\times 30$. From the Redesdale Ironstone Shale. The specimen is from the Nicholson Collection. [Slide G. W. L. 169.] Page 178.

Fig. 10. Dyscritella mitiaria (Nicholson).

Longitudinal section $\times 30$. The same specimen and slide as the preceding.

FiG. 11. Dyscritella ambigua sp. nov.

Longitudinal section $\times 20$. From the top of the Carboniferous Limestone at Penwyllt, South Wales. [Slide G. W. I. 202.] Page 181.

FiG. 12. Dyscritelle ambigua sp. nov.

Tangential section $\times 20$. The same specimen as the preceding. [Slide G. W. L. 201.] Page 181.

FiG. 13. Dyscritella multifida sp. nov.

Longitudinal section $\times 10$. From the Lower Limestone, one and a half miles $\mathrm{N}$. of Croagh, Townland of Cloonoul, Limerick. The original in the Collections of the Geological Survey of Ireland. [Specimen 936 , slide G. W. L. 207.] Page 180.

FIG. 14. Portion of the preceding, $\times 20$.

Fig. 15. Dyscritella multifida sp. nov.

Tangential section $\times 20$, The same specimen as the preceding. [Slide G. W. L. 206.] Page 180 . 
MEMOIRS OF THE GEOLOGICAL SURVEY OF GREAT BRITAIN. Palaeontology. Vol.I,1912.

Plate XVl.
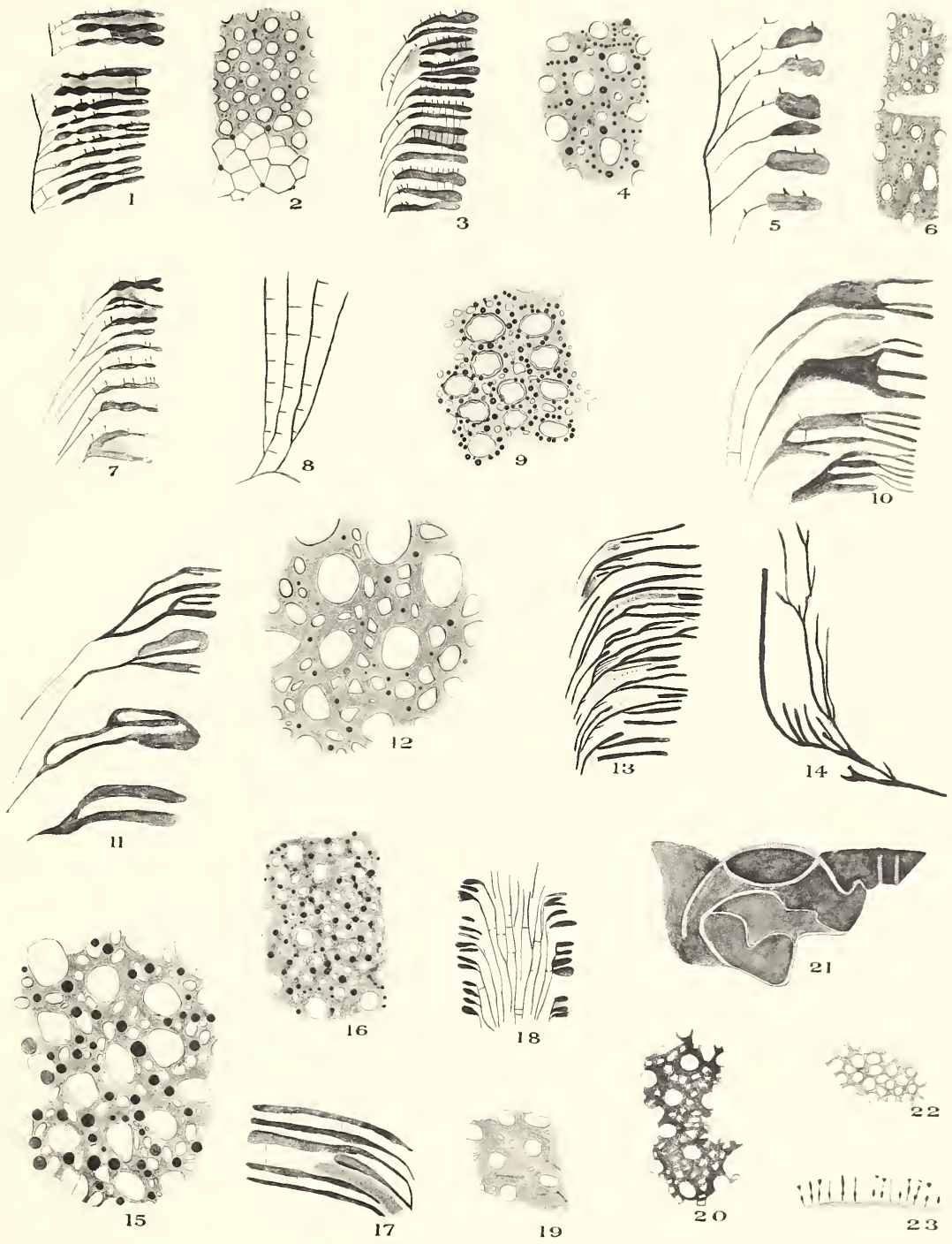

TREPOSTOMATA 
FIG. 16. Batostomella bundorensis sp. nov.

Tangential section $\times 20$. From the Upper Calp Shale of Bundoran, County Sligo 。 [Slide G. W. L. 186.] Page 176.

FIG. 17. Batostomella bundorensis sp. nov.

Peripheral portion of longitudinal section $\times 20$. The same specimen and slide as the preceding. Page 176.

FIG. 18. Dyscritella nana sp. nov.

Longitudinal section $\times 20$. From the Trout Beck, King Water, Cumberland. [Specimen R. 2965, slide G. W. L. 173.] Page 179.

FIGs. 19, 20. Two aspects of a tangential section $\times 20$ cutting the same zoarium. The same specimen and slide as the preceding. Page 179.

FIG. 21. Koninckopora inflata (de Koninck).

Diagrammatic aspect of a section across a large zoarium, natural size. From the "Brachiopod Bed" of Wetton, Derbyshire. The original in the Collection of Dr. A. Vaughan. The portion represented here in black consists of the epizoarium, with some calcite. Page 182.

FIG. 22. Koninckopora inflata (de Koninck).

Tangential section $\times 10$. From the "Brachiopod Bed" of Wetton. The original in the Collection of Dr. A. Vaughan. [Slide G. W. L. 165.] Transparent sections are difficult to prepare; the present one being somewhat obscure, the junction-angles represented here as solid are probably really occupied by cells smaller than the average. Page 182.

FIG. 23. Koninckopora inflata (de Koninck).

Longitudinal section $\times 10$. The same specimen and slide as the preceding. A small portion only of the epizoarium is represented. Page 182. 
$\theta$ 


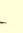




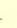


and

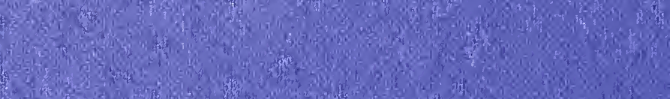

(5)

A

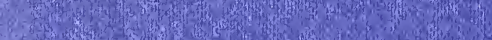

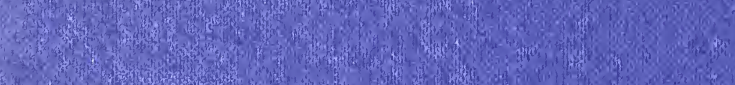

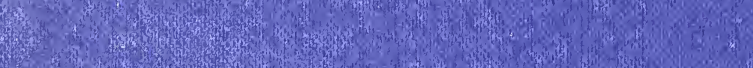

2.

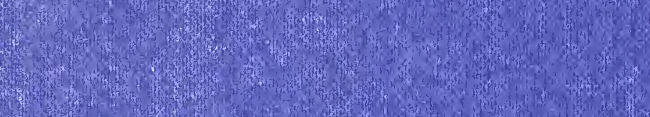

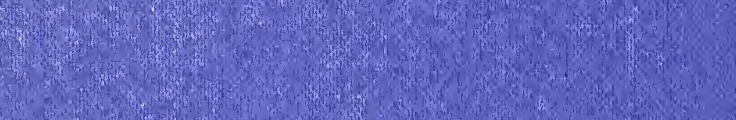

H.

S.t.

15.

of

t.

(4.6.

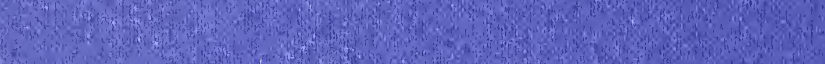

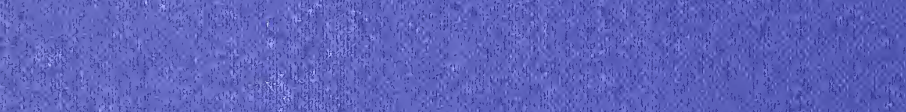

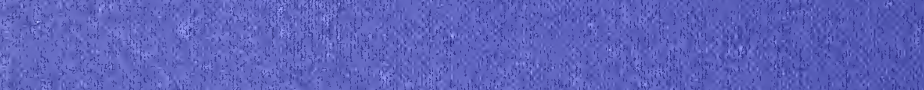

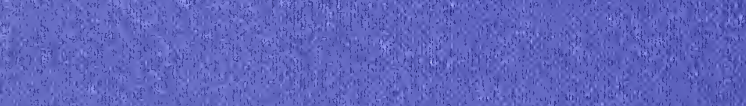

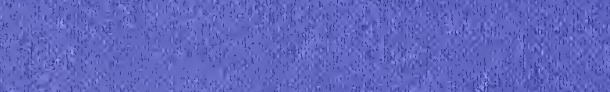

2.5. 3.

W.

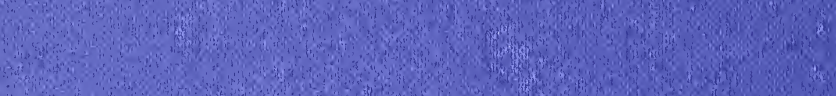

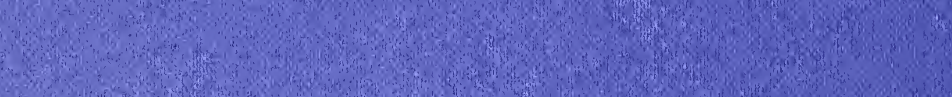

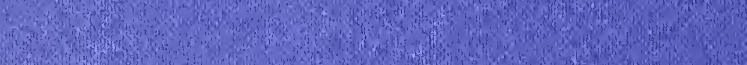

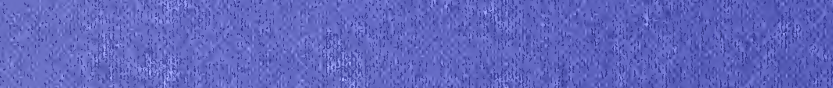

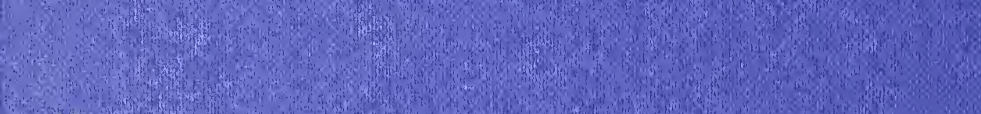

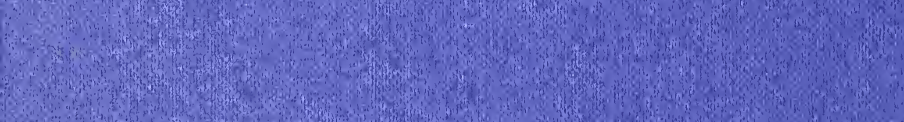

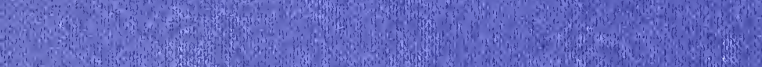

a.

15

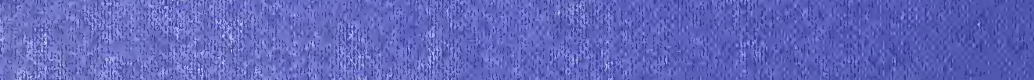
r. 